https://helda.helsinki.fi

\title{
Housing the Russian middle class
}

\section{Khmelnitskaya, Marina}

Routledge

2020-05-05

Khmelnitskaya , M \& Burdyak , A 2020 , Housing the Russian middle class . in J Nikula \& M Chernysh (eds), Social Distinctions in Contemporary Russia : Waiting for the Middle-Class Society? . Routledge, London, pp. 120-149 .

http://hdl.handle.net/10138/325998

acceptedVersion

Downloaded from Helda, University of Helsinki institutional repository.

This is an electronic reprint of the original article.

This reprint may differ from the original in pagination and typographic detail.

Please cite the original version. 


\title{
Housing the Russian middle class
}

\begin{abstract}
The chapter examines the housing situation of the middle class, in comparison to other groups within Russian society. The analysis begins with a qualitative study of government housing policy since the early post-socialist period. It demonstrates that policy measures were not classtargeted, yet had important implications for people residing in accommodation of different qualities and locations and for households with different compositions. The chapter proceeds with a quantitative analysis of the SDMR and GKS-KOUZH-2016 survey data. The analysis reveals that the middle class was slightly better-housed compared to the working class in the objective (having a housing unit of their own and the availability of housing space per person), but particularly in the subjective (feeling a lack of space and the self-reported physical state of a housing unit) senses. The study also demonstrates that the middle class was more active in buying and constructing new housing, and in the use of savings, capital (mostly, existing housing) and mortgage credit to finance those activities. The inequality between classes, at the same time, was less pronounced in terms of what was defined as the 'objective' quality of housing, ownership structure, and the use of funding made available through the Maternity Capital programme. The study, overall, demonstrates that while policies were not classtargeted, with time, class structuration in the Russian housing sphere is expected to become more pronounced.
\end{abstract}

\section{Introduction}

The objective of this chapter is to determine what it means to be middle class in contemporary Russia in terms of housing. ${ }^{i}$ As elsewhere in this volume, we rely on the definition of the middle class based on the professional status and educational characteristics set out in the work of Markku Kivinen (2020: 43, Li et al 2013) and adopted throughout this volume. As people experience housing as households, rather than individuals - although there exist single-person households - in this chapter we refer to pure middle-class households, working-class households, but also mixed class households, where a family consists of representatives of the middle and non-middle classes. Our analysis applies a quantitative methodology and uses the SDMR survey data, also used by other contributions to the volume. In addition, we supplement the SDMR data with the GKS-KOUZH-2016 survey, which contains complementary data related to the housing class structure in Russia. For the SDMR survey we use the KivinenClass variable and for the GKS-KOUZH-2016 we construct a proxy variable based on educational and professional status which corresponds to the KivinenClass variable.

Certain aspects of the housing process - such as home ownership and the use of personal finance - are often ascribed as features of middle-class behaviour. In this chapter, we consider these and other characteristics associated with the housing sphere of the Russian middle class. We also compare the middle class to the strata who do not fit into this category, namely the working class, mixed households (working and middle class) and non-working people. 
Housing tenure type and the use of credit are only some of the aspects of the housing situation of the middle class which we analyse in this chapter.

In Section 1, we review the housing policy of the Russian Government over the past three decades in order to establish which other elements of the housing process we need to pay attention to in order to determine the housing circumstances of the middle class in Russia. We focus on policy measures directly affecting the housing conditions of the Russian people at the time of writing. These include housing privatization, the liberalization of utility prices, the introduction of mortgage borrowing and different measures of social support for specific household categories in the housing sphere. Government policy has created institutional structures which have had a varied impact on housing conditions and generated different housing strategies among different strata of Russian society. Section 2 presents our analysis of the SDMR and GKS-KOUZH-2016 survey data. We concentrate our attention on such aspects as home ownership, quality of housing and subjective housing satisfaction, the use of housing finance, different strategies for improving housing conditions, and attitudes towards the housing sphere and the provision of housing services. The analysis also considers the difference in class housing conditions across different types of settlement (cities, towns, and villages) in Russia and the provision of housing with housing utilities and durable goods between different household types.

\section{Housing policy in Russia in the post-Soviet period}

Since the demise of state socialism and economic planning, the housing situation of the Russian people has been profoundly affected by the emergence and development of a free housing market, new commercial housing construction, the introduction of mortgage finance, and increased migration flows both within the cities and towards large urban centres, notably Moscow and St Petersburg. The depths and speed of housing changes that have occurred in Russia - as well as in other post-communist countries - and the profound role of government policy in these changes means that the statement by a housing scholar that the 'state makes the market' (Clapham 2019) is certainly highly poignant in the context of this transformation.

Government policy was important in initiating and further shaping the political, economic, and social processes associated with housing transformation. Key reform measures in the early 1990s followed the neo-liberal ideology, and included the transfer to the municipal authorities of public housing ownership and management functions, the free privatization of state-built accommodation to sitting tenants, the liberalization of housing maintenance and utility supply, and the introduction of the system of home-mortgage lending (Khmelnitskaya 2014, 2015, Zavisca 2012). These changes were part and parcel of the wider economic restructuring and transformation of Soviet-era enterprises and the divestiture of their social responsibilities, including that for housing provision, towards different levels of state administration, predominantly local and regional. Housing privatization initiated in Russia by the Law on Housing Privatization of 4 July 1991 followed earlier tentative steps towards housing privatization during the years of perestroika in the late-Soviet period (Khmelnitskaya 2015). The process of housing privatization was gradual in character. By 2000, 60\% of accommodation eligible for privatization had turned to private ownership. The remaining $40 \%$ continued being municipally managed and rented to social tenants. Among those households which did not privatize, many perceived no immediate benefits of home ownership. For example, residents of standard accommodation in the urban periphery could not make 
immediate and tangible profits from selling their apartments. By contrast, those who resided in elite blocks of flats located in prestigious areas of capital cities could turn hefty profits by selling their apartments at market prices. Furthermore, many Russians were concerned by the 'dangers' of private ownership, including the potential higher tax burden, and the responsibility for costly maintenance and major repairs (kapital'niy remont) of their blocks of flats. The costs associated with the latter were particularly concerning. Much of the housing stock was in bad need of repair and the new owners were to bear the costs.

The socio-economic context of the transition period in the 1990s was important. The sharp reduction of incomes and the loss of savings due to galloping inflation resulted in a situation where the housing sector played the role of a 'shock absorber'. This related not only to giveaway privatization, which transferred significant housing wealth to individual households, but also to the housing utilities and to maintenance costs that were kept at artificially low levels. The opposition to the Government's neo-liberal plans, first in the Supreme Soviet, and then in the State Duma, prohibited sharp increases in housing and utility costs being charged to the users. Such increases, the opposition argued, would have resulted in mass non-payments because of the lack of the population's disposable income: in 1992-93 up to 33\% of the population lived below the poverty line. ${ }^{\mathrm{ii}}$ The number of the poor gradually diminished to $21 \%$ by 1997 but peaked again at 29\% in 1999-2000. In the second half of this chapter we examine the attitudes towards housing and utility services among the Russian middle class as well as other groups. We consider the complex question of whether the legacy of the social provision of housing and utilities during the Soviet period, paired with the experience of artificially low housing charges in the 1990s, resulted in the expectation of free or heavily subsidized provision of these goods by the state among Russians by the mid-2010s.

In the 1990s, the parliamentary opposition continued to block the adoption of a new Housing Code involving a more far-reaching change in the regulation of the housing sphere. The advocates of the liberal reforms were committed reformers within successive Russian governments under President Yeltsin and their international advisors. Among the most contested issues were the already mentioned responsibility for the costs of major housing repairs and the extent of the state's responsibility for the provision of social housing. The introduction of such changes was awaiting a more amenable political situation. This emerged with Vladimir Putin's arrival in power in 2000. The election of the United Russia-dominated executive-friendly lower house of parliament at the end of 2003 meant that the State Duma finally voted for the government's version of the Housing Code at the end of 2004 (Khmelnitskaya 2015). The code was adopted simultaneously with the infamous monetization of social benefits, greeted with widespread protests by pensioners. The fact that the adoption of the new radical neo-liberal Housing Code did not attract a comparable amount of popular criticism - apart from some critical commentary from the expert community - can be explained from the perspective of political science. This was a case where the potential losers from the reform did not perceive how the reform could disadvantage them and were insufficiently organized anyway, whereas those who gained from the introduction of new policy mechanisms, particularly a group of determined neo-liberal policy-makers, saw 'a window of opportunity' opening for them with the emergence of the parliamentary majority and pushed through the policy change (see Gel'man and Starodubtsev 2016). The reduction in the state commitment on the provision of public housing to the $5 \%$ of the population on the lowest incomes, and the transfer of the costs of major repairs of multi-family residential buildings to the property

[Type here] 
owners, also promised considerable savings of state budget funds. In practical terms, prior to the adoption of the 2004 Housing Code, all households residing in dwellings with floor space below a socially guaranteed norm (of 10 square metres in Moscow and 9 in St Petersburg, ${ }^{\text {iii }}$ while it differs across the regions) could be placed on municipal housing 'waiting lists'. After the Code came into force, the principle of means-testing was applied. Thus, only the households on the lowest incomes and living in overcrowded housing were entitled to receive social housing.

Where the state left off, the market was expected to take over. The system of mortgage finance was introduced in Russia in 1996 with the establishment of the Agency for Home Mortgage Lending (AHML) (Khmelnitskaya 2014). At the time of its introduction, mortgage loans were expensive and accessible only to the highest earners. Nonetheless, housing wealth which Russian families received in the process of housing privatization could be used to improve their housing conditions. The combination of housing privatization with the gradual development of mortgage finance and the simultaneous withdrawal of the state from the social provision of housing signified the establishment of the 'paradigm' of predominantly private home ownership. Housing finance started developing more steadily in the 2000s as economic performance improved and household incomes started to grow. Its development was held back to an important extent by the underlying weakness of the Russian banking sector. Nevertheless, by $201630 \%$ of housing transactions were financed with the use of mortgage loans. The figure was at its highest in the Moscow region, at 80\% (Khmelnitskaya 2017a).

Overall, housing privatization, the developing housing market, and the introduction of mortgages have entirely transformed the Russian housing sphere and ownership structure. By 2017, according to Rosstat data, $81 \%$ of the housing stock that was eligible for privatization had been privatized (Rosstat 2019), and $91.5 \%$ of housing was held in private ownership, ${ }^{\text {iv }}$ creating a nation of 'super-home-ownership'. The continuing weakness of the Russian banking industry, however, had another important implication for the housing sector. Due to the lack of alternative investment options, housing became a prime destination for investment, allowing citizens to store value in the form of 'investment apartments'. Respectively, many owners of second and further apartments chose to rent those out to return some of the investments made. In addition, the ownership of several housing units was also a result of intergenerational property transfers, when children and grandchildren inherited property from older family members. An important aspect was that the investment and rental attractiveness of housing varied by region. Moscow especially, but also St Petersburg and Sochi, were cities with high migrant inflows (Burdyak 2017). Thus, in the early 2010s these regions offered the highest returns on investment and realised the highest house prices.

The role of the state in providing social housing and related benefits displayed significant regional variance, too. The provision of social housing became the responsibility of the regions. The regions continued to maintain housing waiting lists, infamous since the Soviet era (Attwood 2010). However, what happened to those placed on the lists depended on the financial resources of a given region. The provision across Russia remained low. Only 5\% of households on waiting lists were allocated social housing in 2017, or 122,000 out of 2,458,000 families in need ${ }^{\mathrm{v}}$ (Rosstat 2019). Federal policy prioritized large families, those with disabilities, and orphans leaving institutional or foster care. Yet, in the majority of cases any significant change to the housing circumstances of those placed on the waiting lists resulted either from natural causes (generational changes in the household structure) or from 
individuals, particularly young families, taking action with regard to their housing situation using the market mechanisms available (Bogomolova and Cherkashina 2018). As far as the 'non-priority' groups were concerned, the regional authorities aimed to promote market housing while offering a certain degree of social assistance. An example of such initiatives was the 'social mortgages offered with city support' in Moscow, starting from the mid-2000s. Moscow, being one of Russia's wealthiest regions, could afford such social assistance for home purchases. By contrast, other, less affluent regions, particularly under conditions of severe budget scarcity in the mid-2010s (see Zubarevich et al. 2017), tended to put off the provision of social housing, leaving it to natural causes or private initiatives to take care of individual housing needs.

Against this background, from the second half of the 2000s onwards, experts and everyday citizens alike began to express their discontent with the highly limited availability of housing options. The key problem concerning the vast majority of Russians was that they were not rich enough to afford market prices but not sufficiently poor to expect any form of housing assistance from the state. They essentially represented the housing affordability gap. In the opinion of many, the situation deteriorated even in comparison with the Soviet period, which was notorious for its housing shortages and time spent on housing waiting lists.

This perception coincided with growing concern about Russia's demographic outlook, gaining momentum in the mid-2000s following the agenda set out in the 2005 Presidential Address to the Parliament (Putin 2005). In addition, research has underlined the subjective association that the Russian people, as well as those in other East European nations, make between their housing circumstances and their ability to form a family and have children (see Zavisca 2012). Policy emphasis on housing affordability - particularly among young families - therefore, stemmed from a combination of factors, including growing popular dissatisfaction, leadership priorities, and subjective cultural perceptions. Thus, in the late 2000s and after we have observed a number of new measures being introduced, such as the Corporation (Fund) for Housing Repairs, the Corporation (Fund) to Assist New Housing Construction, the National Affordable and Comfortable Housing Project, and the Maternity Capital initiative introduced in 2007 (Khmelnitskaya 2017a, b, Grishina and Tsatsura 2018) and various measures to provide subsidized mortgages for families with children. For instance, the 'children's mortgages' (detskaya ipoteka) introduced in 2018 was designed for families with a new-born child at a $6 \%$ interest rate for 3 to 8 years and at a reduced rate for the rest of the lending period (see Burdyak, Lyashok and Maleva 2018: 63-5).

The Maternity Capital was a large lump-sum benefit to any mother who had a second child. The size of the Maternity Capital was 453,000 rubles in 2016-2018 (PFRF 2018a). However, its purchasing power varied, depending on the region. Taking into account the house price difference between the regions, this sum of money was more significant in the provinces with lower house prices, as opposed to hyper-expensive Moscow and St Petersburg. Although, according to its regulations, the sum that the programme distributes for the birth of the second child can be invested in the mother's pension savings, the child's education, or disability rehabilitation, the majority of those who have received and used the Maternity Capital certificate $-91 \%$ or around 5 million families (PFRF 2018a) - have used it to improve their housing conditions: 3.3 million have used the money to take out or repay a mortgage loan. In the meantime, the Pension Fund of Russia, which is responsible for paying out this benefit, 
gives the overall number of recipients of the Maternity Capital certificate by 2018 as 8.9 million households (PFRF 2018b).

Other measures included attempts to promote rental accommodation. The importance of the development of affordable commercial (as opposed to social) rental housing types was reflected in many policy documents of the late 2000s and the early 2010s, for example the State Programme on Housing adopted in April 2014 (Gossudarstvennaya programma 2014). However, the results of this policy were less than encouraging, primarily because the local authorities and the construction industry lacked incentives to develop this type of housing (Khmelnitskaya 2017a). Moreover, the change in the economic context in the mid-2010s affected the housing and mortgage markets. With the drop in the value of the ruble in 2014, housing prices in many Russian regions have stagnated or decreased (Maleva 2017). The continued new housing construction further added to the supply side of the market. Consequently, housing lost its investment attractiveness (ibid) and the proportion of the demand fuelled by investment motives by and large disappeared. This produced a situation in the rental market with plenty of availability of new investment apartments in large cities. In smaller towns, by contrast, private housing rent was rather affordable - cheap in fact. Some pensioners provided rental accommodation, often a room, at a price that simply allowed them to cover their communal service charges.

Besides, as the housing privatization that had been underway since the early 1990s was made permanent in February 2017 by an amendment to the 2004 Housing Code (Khmelnitskaya 2017c), this decision affected local governments' incentives to develop social housing. Such housing could at any time 'be lost' to privatization. As a result, by the late 2010s, housing privatization was described by many observers as an obstacle constraining further balanced development of the housing sphere in Russia (e.g. Artem'ev 2019).

Finally, policy-makers continue with the measures to liberalize the Russian housing sphere. Through the 2000s and 2010s, efforts continued to increase housing and utility service (HUS) charges. In 2011-2013 the users covered $90 \%$ of the HUS costs, the rest being subsidized from the budget. In 2016-2017 the figures were $94.3 \%$ and $95.5 \%$ respectively. Non-payments were low: in 2017 just $4.3 \%$ (Maleva 2018). This was nearly negligible compared to the level of non-payments in the 1990s.

Overall, during the early post-Soviet period and in the 2000s liberalization was the key development in the Russian housing sphere. Over this period, private ownership of housing climbed to $91.5 \%$. Government policies, however, were not class-targeted. The targeting that occurred was addressed towards families with children, an emphasis connected to demographic concerns rather than class inequality.

\section{Housing the middle class: analysis of the SDMR and GKS-KOUZH-2016 survey data}

In this section we examine the housing situation of the Russian middle class, and by implication other groups within Russian society. Essentially, we ask: what does it mean to be middle class in Russia in terms of housing? Our analysis includes such characteristics as objective and subjective living conditions, ownership structure, different strategies to improve housing conditions, the use of Maternity Capital, timely payments for housing and communal services, and attitudes towards the responsibility for the housing sphere. We also consider differences 
between cities, towns, and villages and how the housing conditions of different class groups differ in terms of their provision with utilities and certain durable goods.

Two sources of data are used: the SDMR survey - which is used by other contributors to this volume - and the GKS-KOUZH-2016 survey conducted by Rosstat. ${ }^{\text {vi }}$ From the SDMR data we examine three waves of the survey: 1998, 2007, and 2015. The SDMR contains a number of questions addressing the housing situation of Russian households. Particularly relevant questions include those on the type of the dwelling, floor space per household, receipt of Maternity Capital, and attitudes towards the housing sphere. These allow us to make important observations about the housing situation of the Russian middle class and its comparison with other segments of society. Yet, in order to present the reader with a broader picture of the housing characteristics of the middle class in Russia, we supplement the SDMR with Rosstat's Comprehensive Monitoring of Living Conditions 2016 survey (GKS-KOUZH-2016). A few words on this data source are in order. The GKS-KOUZH-2016 covers 60,000 Russian households, or 135,000 people, and is representative of all the population. Weighting is applied. We constructed a proxy for the Kivinen middle-class indicator based on the profession code ISCO and the presence of higher education. Our proxy variable, therefore, corresponds with the Kivinen_Class08 variable used for analysis by other contributors to the present volume. Further, as noted, given that people live in housing as households, we cannot consider housing as an individual characteristic, thus we need to construct household categories. Therefore, individual Kivinen middle-class indicators were aggregated into a household variable. If all working members of a household belong to the middle class, we classify the household as a middle-class household (15.5\%). Likewise, a household belongs to the working class $(47.2 \%)$ if all employed members of such a household are classified as working class. Finally, households with both types of employees are called 'mixed type' $(11.5 \%)$. The rest of the sample consists of non-working families $(25.8 \%)$. Most in this category are retirees. See Figure 1 vii $^{\text {vii }}$

Figure 1 - Household distribution by strata, \%

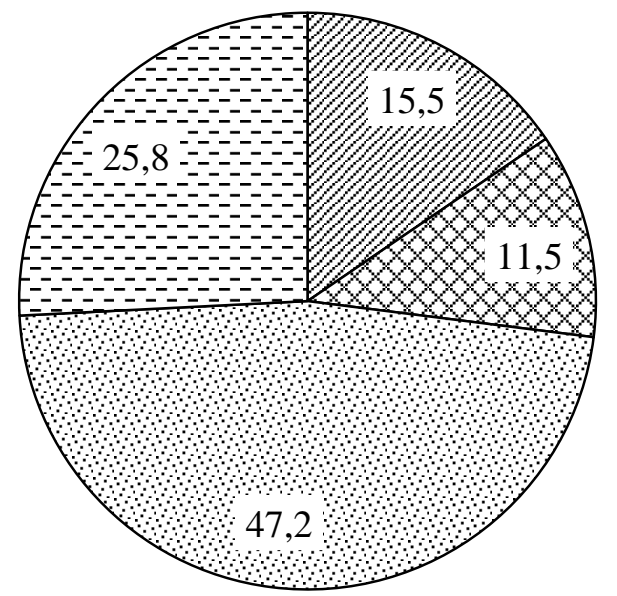

ఐ Middle class households

冈Mixed type of households

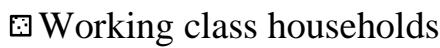

$\boxminus$ No working adults in the households

Source: Calculations on GKS-KOUZH-2016 data 


\section{Objective and subjective housing conditions of Russian households}

We begin with the objective living conditions of the Russian middle class. By 'objective' we understand those results expressed in numerical indicators, for instance having a housing unit of their own and the quantity of housing expressed in square metres, which are considered below. Later this sub-section moves on to 'subjective' housing characteristics based on individuals' self-reported perceptions of the lack of housing space they are experiencing and the self-assessed quality of their housing. In other words, the 'subjective' is about perceptions and feelings.

The objective housing conditions of the middle class and the other strata of the adult population in Russia can be assessed using several waves of the SDMR survey and its question on the type of the housing unit. In 1998 and 2007 surveys we can identify whether the person lives in their own house; a one, two, three, four, or more roomed apartment; in a communal apartment; in a dormitory; in barracks; or in a rented apartment. In the 2015 survey, the number of rooms in the apartment was left out of the questionnaire, therefore in the dynamic analysis for 19982007-2015 we aggregate one, two, three, four, or more roomed apartments in one category designated 'apartments'. An important point to be mentioned is that we consider communal apartments, dormitories, and barracks as poor housing conditions. They are aggregated into a single category. Fortunately, the data shows that not too many working people reside in such housing: from $3 \%$ to $6 \%$ in different years. See Figure 2.

Figure 2 - Type of housing of the core and margin of middle-class and working-class representatives for 1998-2007-2015, \%

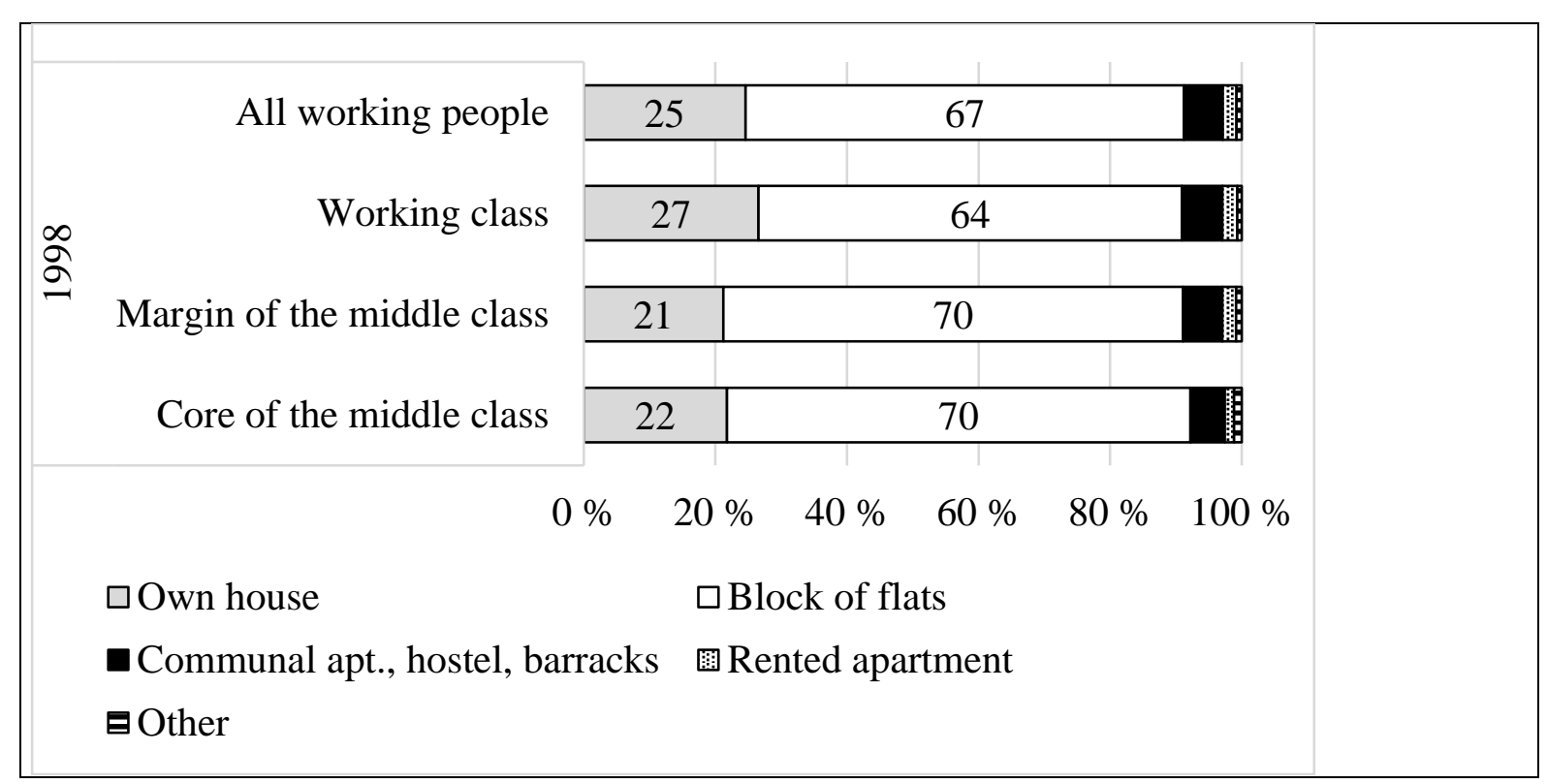




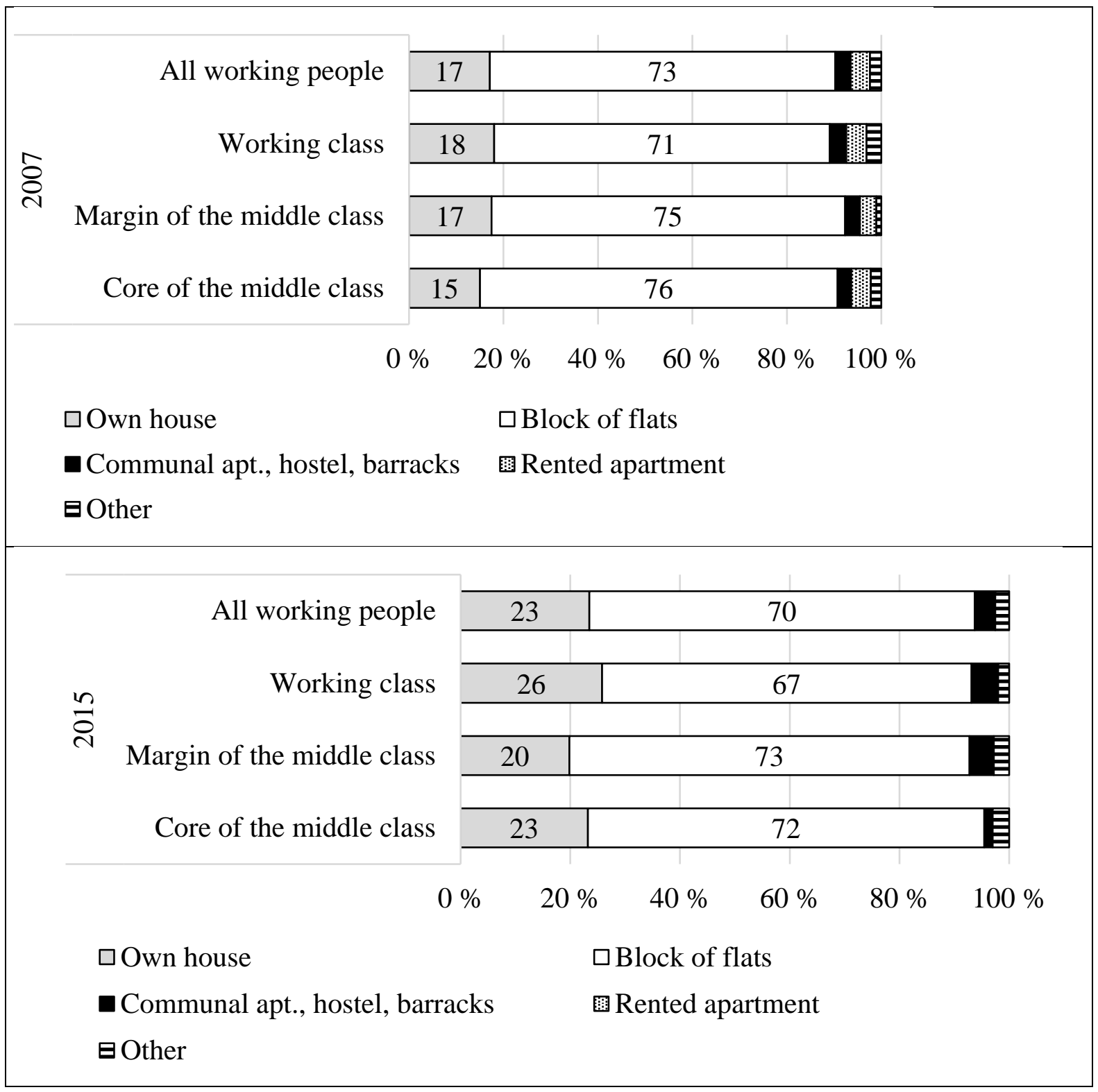

Source: Calculations on SDMR data, Sdmr_mergewithKivinenClass_spss.sav

As the data shows convincingly, the main type of housing condition in the Russian Federation is an apartment in a block of flats. Among all working people surveyed in the SDMR $67 \%$ in 1998, 73\% in 2007 and 70\% in 2015 lived in apartments. Their own house is the residence of $25 \%$ in 1998, 17\% in 2007 and $23 \%$ in 2015 . The increase in the number of households residing in apartments observed in 2007 must be due to a shift in the sample toward apartment residents, rather than an indication of a real social change. 
Table 1 - Type of housing of core and margin of middle-class and working-class individuals for 1998-2007-2015, \%

\begin{tabular}{|c|c|c|c|c|c|c|c|c|c|c|c|c|}
\hline & \multicolumn{4}{|c|}{2015} & \multicolumn{4}{|c|}{2007} & \multicolumn{4}{|c|}{1998} \\
\hline & 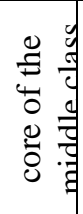 & 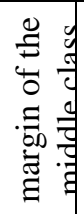 & 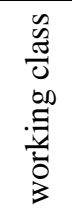 & $\begin{array}{l}\frac{0}{2} \\
\bar{D} \\
\stackrel{\Xi}{2} \\
\bar{Z}\end{array}$ & 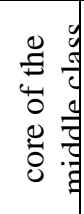 & 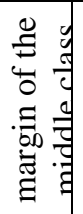 & 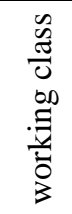 & $\begin{array}{l}\frac{0}{\pi} \\
\frac{0}{0} \\
\frac{2}{2} \\
\frac{1}{Z}\end{array}$ & 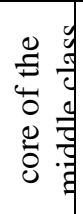 & 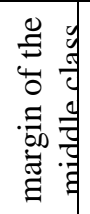 & 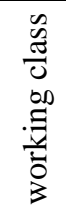 & $\begin{array}{l}\frac{0}{2} \\
\frac{0}{0} \\
\frac{\Xi}{Z}\end{array}$ \\
\hline Own house & 23.2 & 19.8 & 25.8 & 23.5 & 15.0 & 17.5 & 18.0 & 17.1 & 21.7 & 21.2 & 26.6 & 24.6 \\
\hline Block of flats & 72.2 & 73.0 & 67.3 & 70.2 & 75.7 & 74.8 & 71.0 & 73.2 & 70.4 & 69.9 & 64.4 & 66.6 \\
\hline Rooms in a communal apartment & 1.2 & 2.7 & 2.5 & 2.1 & 2.2 & 1.7 & 2.6 & 2.3 & 3.5 & 3.4 & 3.3 & 3.3 \\
\hline A room in a hostel & 0.4 & 1.3 & 2.3 & 1.5 & 0.6 & 0.3 & 0.7 & 0.6 & 1.4 & 1.7 & 2.0 & 1.8 \\
\hline Rooms in barracks & 0.0 & 0.4 & 0.1 & 0.1 & 0.0 & 1.0 & 0.2 & 0.3 & 0.3 & 0.8 & 0.9 & 0.7 \\
\hline $\begin{array}{r}\text { Communal apt., hostel, barracks } \\
\text { (subtotal) }\end{array}$ & 1.5 & 4.4 & 4.9 & 3.8 & 2.9 & 3.1 & 3.5 & 3.2 & 5.2 & 5.9 & 6.1 & 5.9 \\
\hline Rent & 0.0 & 0.0 & 0.0 & 0.0 & 4.2 & 3.5 & 4.3 & 4.1 & 1.4 & 2.1 & 2.3 & 2.1 \\
\hline Other & 3.0 & 2.8 & 2.0 & 2.5 & 2.2 & 1.0 & 3.1 & 2.4 & 1.2 & 0.8 & 0.7 & 0.8 \\
\hline All & $\begin{array}{r}100 . \\
0 \\
\end{array}$ & $\begin{array}{r}100 . \\
0 \\
\end{array}$ & $\begin{array}{r}100 . \\
0 \\
\end{array}$ & $\begin{array}{r}100 . \\
0 \\
\end{array}$ & $\begin{array}{r}100 . \\
0 \\
\end{array}$ & $\begin{array}{r}100 . \\
0 \\
\end{array}$ & $\begin{array}{r}100 . \\
0\end{array}$ & $\begin{array}{r}100 . \\
0 \\
\end{array}$ & $\begin{array}{r}100 . \\
0 \\
\end{array}$ & $\begin{array}{r}100 . \\
0\end{array}$ & $\begin{array}{r}100 . \\
0 \\
\end{array}$ & $\begin{array}{r}100 . \\
0 \\
\end{array}$ \\
\hline
\end{tabular}

Source: Calculations on SDMR data, Sdmr_mergewithKivinenClass_spss.sav

Our main interest, however, is the difference between the overall distribution of working people across types of dwelling and that of the middle class. Is the middle class better off in terms of having a housing unit of their own? The data demonstrates that the core of the middle class is certainly better-housed: fewer of its members do not have a separate place to live, residing in communal apartments, dormitories, and barracks. The margin of the middle class, by contrast, looks just slightly better off than the working class. Yet, the gap is too small to be considered a significant disparity between these two groups. Another important observation is that the core and margin groups of the middle class tend to be housed in blocks of flats, whereas a larger proportion of the working class reside in individual houses. This difference can be explained by the fact that the middle class tends to be urban and gravitates towards larger cities, where individual houses are rare, whereas a greater proportion of the working class reside in smaller towns and rural areas with a larger share of individual housing buildings.

Figures 3 and 4 illustrate this point. While in large cities (one million inhabitants and more) $25 \%$ of households belong to middle class people, in cities with 100,000-249,000 inhabitants the share of the middle class is $17 \%$. In rural settlements $5-8 \%$ of inhabitants belong to the middle class. This is largely determined by the structure of the labour market and the availability of middle-class jobs in different settlement types. The predominance of apartment housing or individual houses in urban and rural areas is also contingent on external factors, rather than linked to class belonging. 
Figure 3 - Household distribution by type of settlement, \%

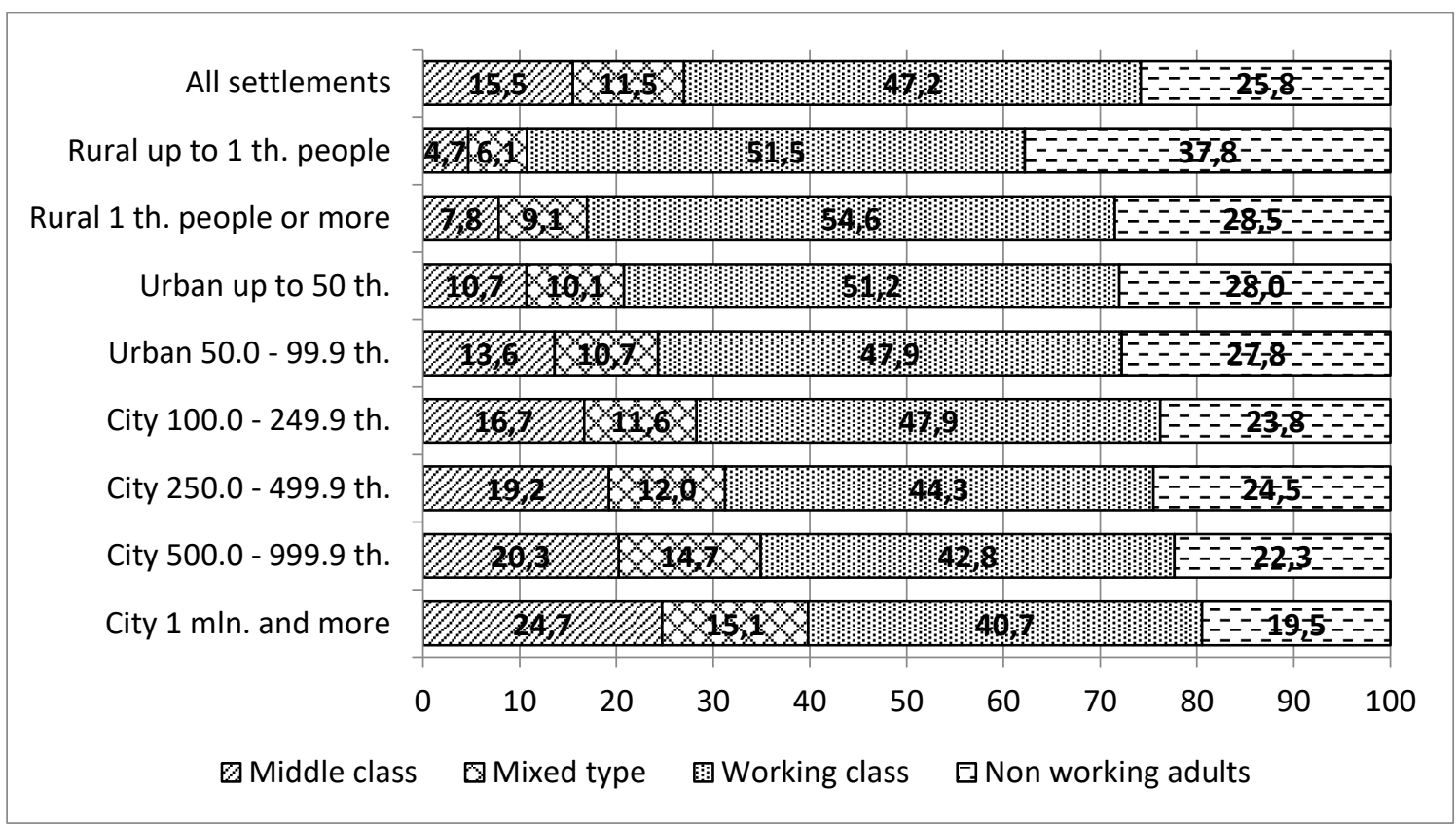

Source: Calculations on GKS-KOUZH-2016 data

Figure 4 - Type of dwelling by type of settlement, \%

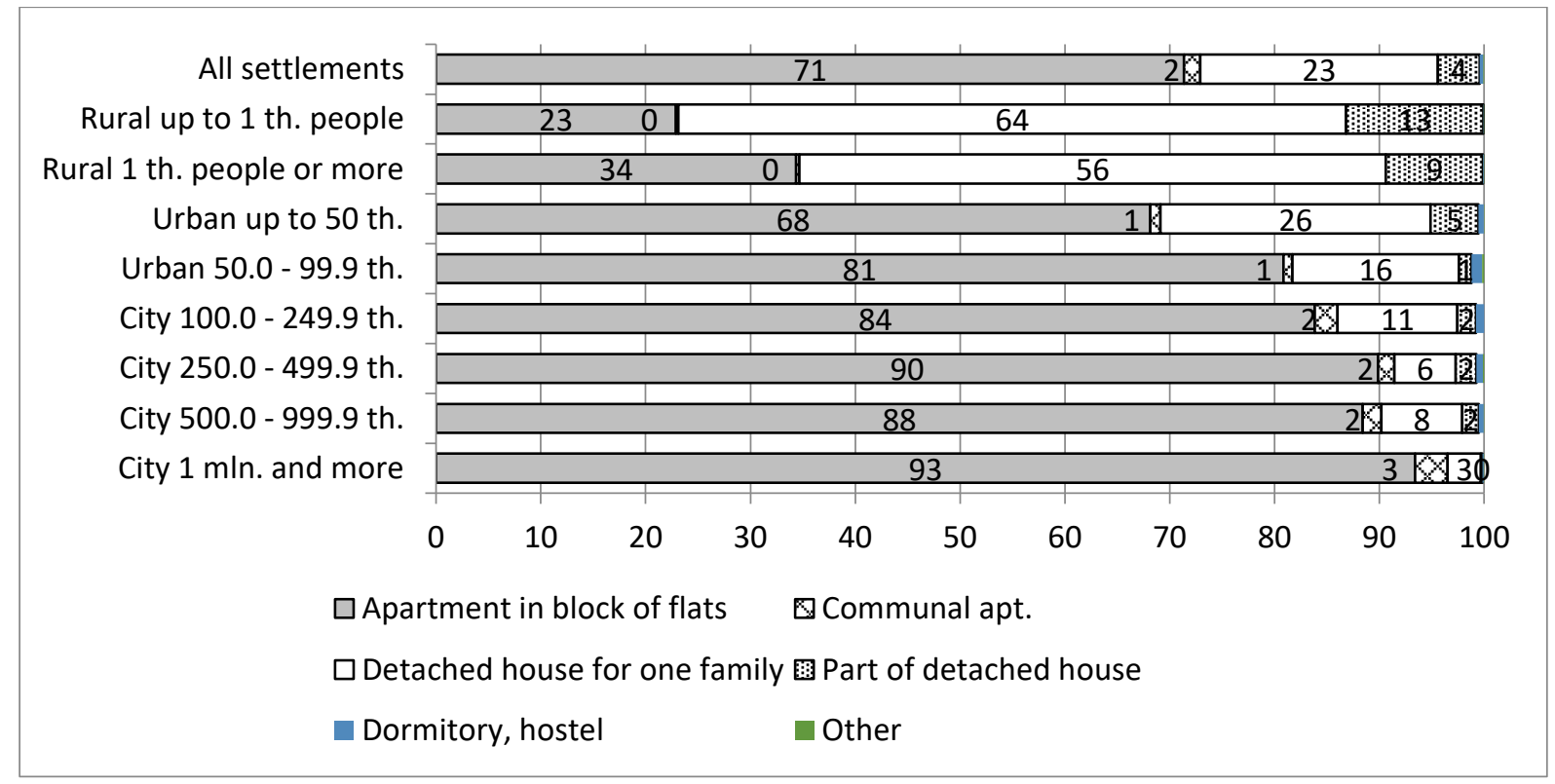

Source: Calculations on GKS-KOUZH-2016 data

The next 'objective' characteristic of the housing situation of the Russian middle class is the quantity of housing space per person. This characteristic is also often referred to as overcrowding. Table 2 and Figure 5 present the per-capita aggregate space of a house or apartment by strata. An average number of square metres (22.1) per one member of a household 
surveyed by SDMR-2015 viii is comparable to the square metres per person reported by the Russian statistical service, Rosstat, for 2015-2016, also included in Table 2.

Table 2 - Mean and median aggregate space of houses or apartments by strata, sqm. per capita

\begin{tabular}{|l|c|c|}
\hline & Mean & Median \\
\hline Core of the middle class & 21.9 & 18.3 \\
\hline Margin of the middle class & 21.5 & 17.5 \\
\hline Working class & 19.8 & 16.7 \\
\hline All working people & 20.8 & 17.5 \\
\hline SDMR-2015, total & 22.1 & 18.7 \\
\hline Rosstat, 2015 & 21.7 & \\
\hline Rosstat, 2016 & 22.8 & \\
\hline
\end{tabular}

Source: Calculations on SDMR-2015 data and Rosstat ${ }^{\mathrm{ix}}$

The data show that the core of the middle class enjoy greater housing availability compared to the working class. The difference between these strata is 2.1 sq. $\mathrm{m}$ in mean and $1.6 \mathrm{sq} . \mathrm{m}$ in median values. The margin of the middle class, at the same time, is somewhere between those two groups. Overall, similarly to the first characteristic of having a housing unit of their own, the Russian middle class on average is better off in terms of the availability of the housing space per person compared to the working class (see Figure 5). Non-employed people, especially pensioners, have more spacious housing in per-capita terms - this is the reason why the total average SDMR figures are higher than those for the working people sub-sample.

Figure 5 - Mean and median aggregate space of a house or apartment by strata, sq.m. per capita

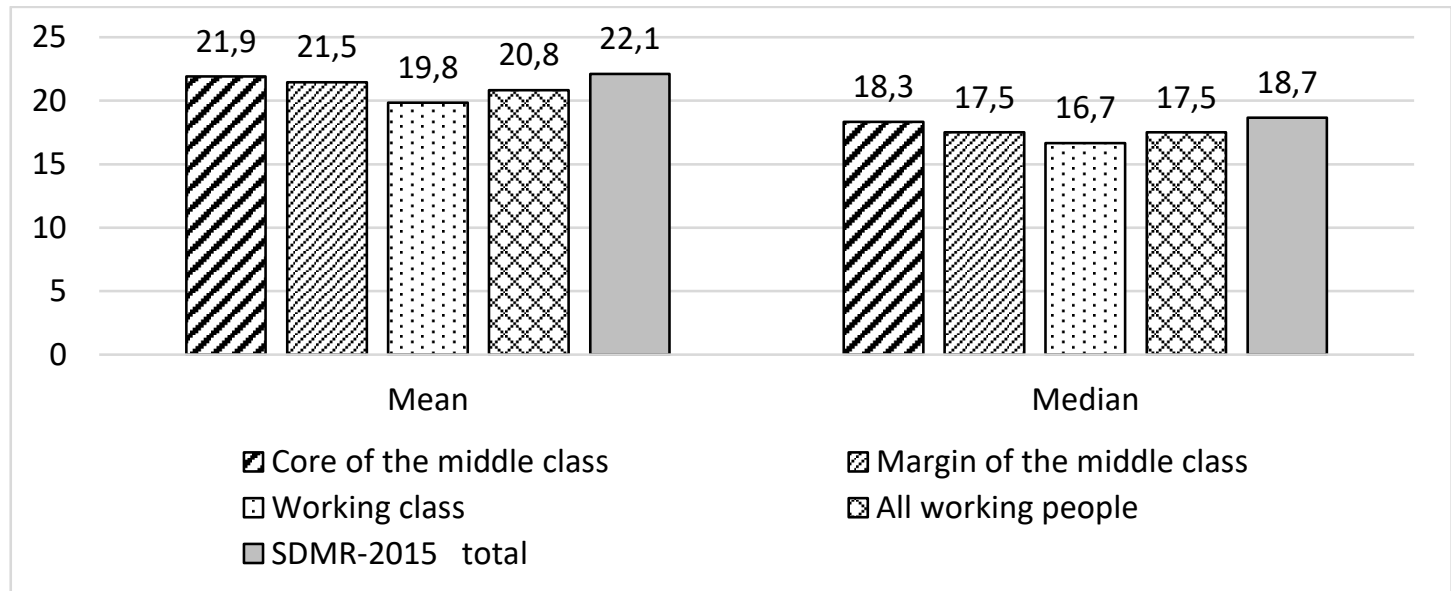

Source: Calculations on SDMR-2015 data

Yet, a closer look at the distribution of per capita housing space in intervals reveals that it is the core of the middle class that has the greatest housing availability across the whole distribution. It perhaps appears somewhat surprising that among the margin of the middle class group a greater proportion in comparison to the working class reside in overcrowded housing (up to 9 sq. $\mathrm{m}$ and 9-11 sq. m) (see Figure 6). This could be because many in this group are families with small children or young specialists with good educations and job positions who have reached the margin of middle-class status in our classification, yet, have not so far had 
the chance to move to better housing. It is also noteworthy, however, that for the intervals from 15 sq. $\mathrm{m}$. and higher we find more representatives of the margin of the middle class having greater housing space availability compared to that of the working class.

Figure 6 - Per capita space of a house or apartment by strata in intervals, \%

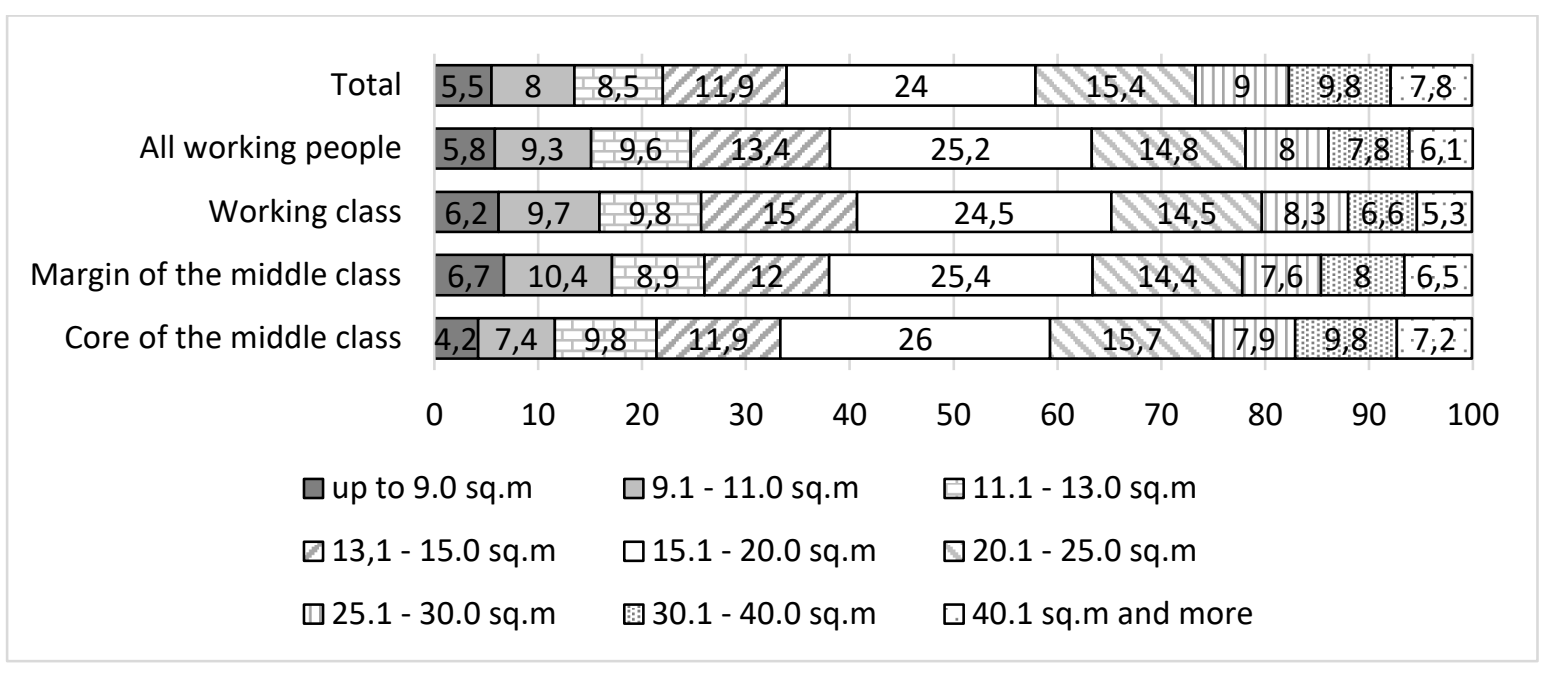

Source: Calculations on SDMR-2015 data

In order to examine the subjective - i.e. based on individuals' self-reported perceptions and feelings about their housing conditions - characteristics of the housing conditions of the different strata in Russia, we turn our analysis to the GKS-KOUZH-2016. This data presented in Figure 7 demonstrates that, according to personal perceptions, the house or flat was too small for $10 \%$ of the working class and $6 \%$ of the middle class. Another $22 \%$ of the working class and $20 \%$ of the middle class felt some constraints in terms of housing space availability. The problem of small dwellings was most acute for the mixed type of households. By definition, they comprise two individuals or more, while the three other categories contain a certain proportion of single-person families. As a rule of thumb, the bigger the family, the more likely it is to face a lack of housing space when compared to those living alone.

Figure 7 - Households experiencing lack of space in their main dwelling by strata, \%

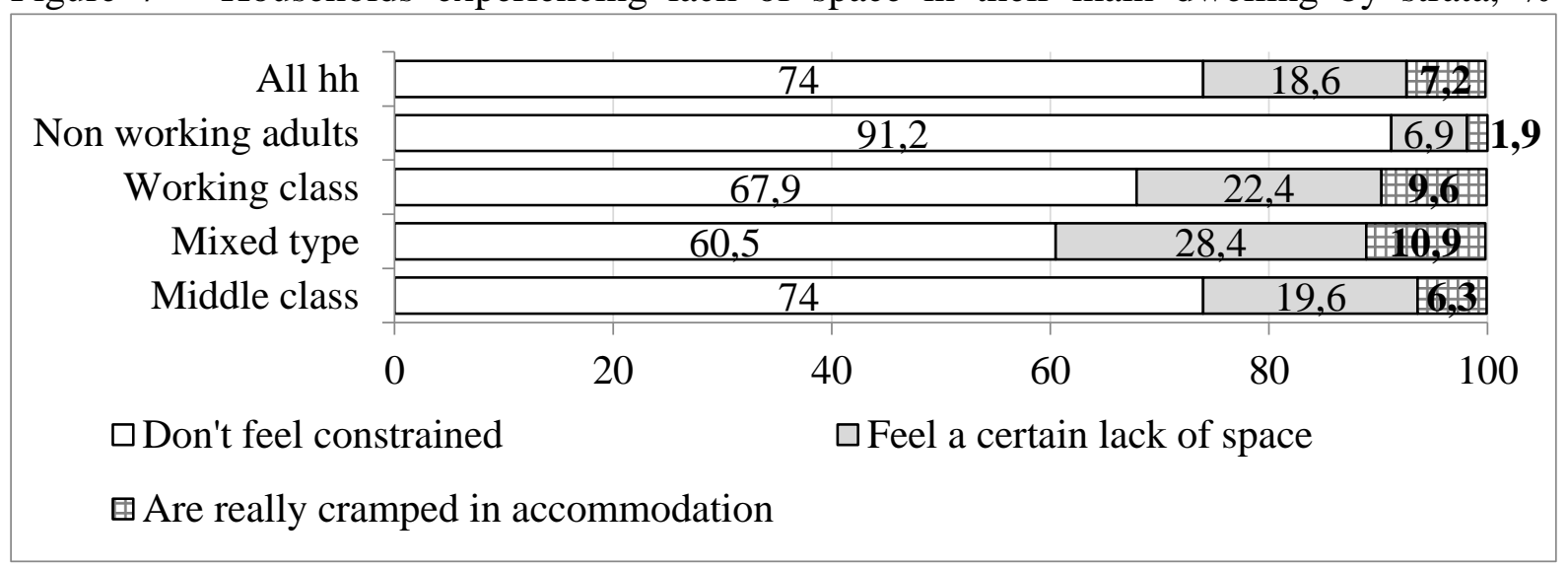

Source: Calculations on GKS-KOUZH-2016 data 
Another subjective characteristic relates to the personal assessment of the physical condition of the housing units. Here we get $6 \%$ excellent, $45 \%$ good, and $44 \%$ satisfactory responses across all households (Figure 8). This shows, that based on individual perceptions, Russian housing is in a rather good physical state overall. Nevertheless, $5 \%$ of households live in bad or very bad dwellings. The difference between the middle and working classes is striking: $61 \%$ of the former reside in good or excellent dwellings and $2 \%$ assess their homes as being in a bad or very bad condition. By contrast, among the latter, only $48 \%$ reside in good or excellent dwellings, while $6 \%$ report their bad or very bad physical state.

Figure 8 - Personal assessment of the physical condition of the dwelling by strata, $\%$

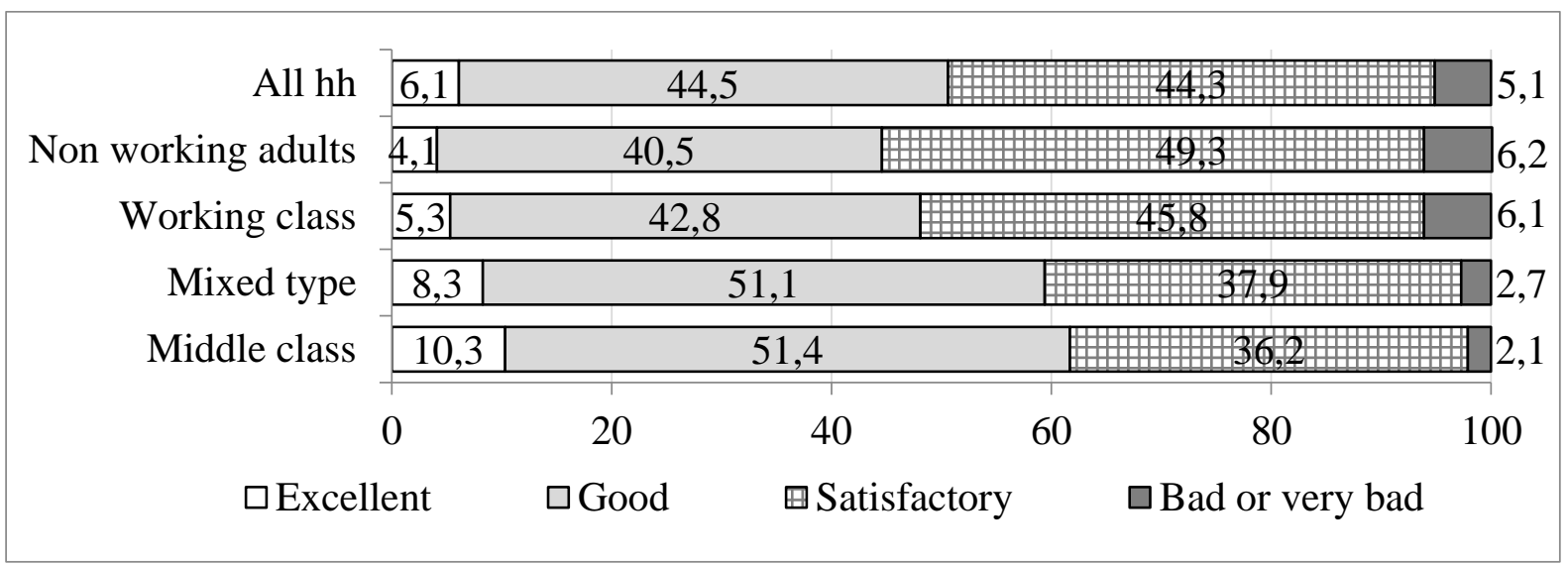

Source: Calculations on GKS-KOUZH-2016 data

Looking through the prism of the type of settlement, the data reveals the problem of the bad physical conditions for different classes to be the most severe in smaller settlements. Across all settlement types - cities, towns, and villages - representatives of the middle class are better off in terms of the physical condition of their flats or houses. See Figure 9.

Figure 9 - Bad dwellings by strata and type of settlement, \%

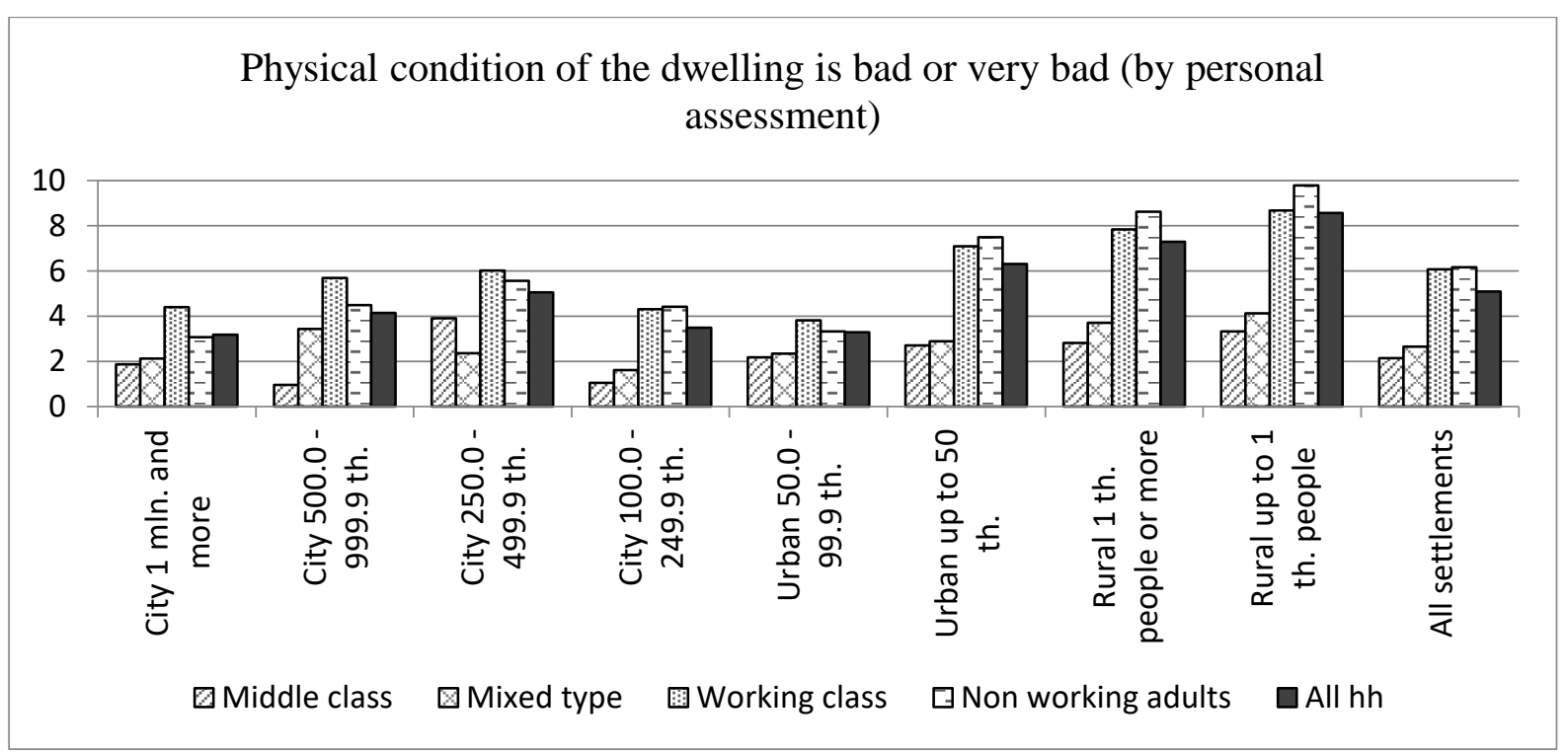

Source: Calculations on GKS-KOUZH-2016 data

[Type here] 
On the contrary, smaller accommodation is more prevalent in big cities. Figure 10 shows that the problem is more acute for mixed and working-class households across the board, but especially in larger urban areas. The non-working households, mostly pensioners, experience the least overcrowding, as the data show. In this case, the middle class is also better off compared to the working class in terms of overcrowding across all settlement types.

Figure 10 - Feel cramped in dwelling by strata and type of settlement, \%

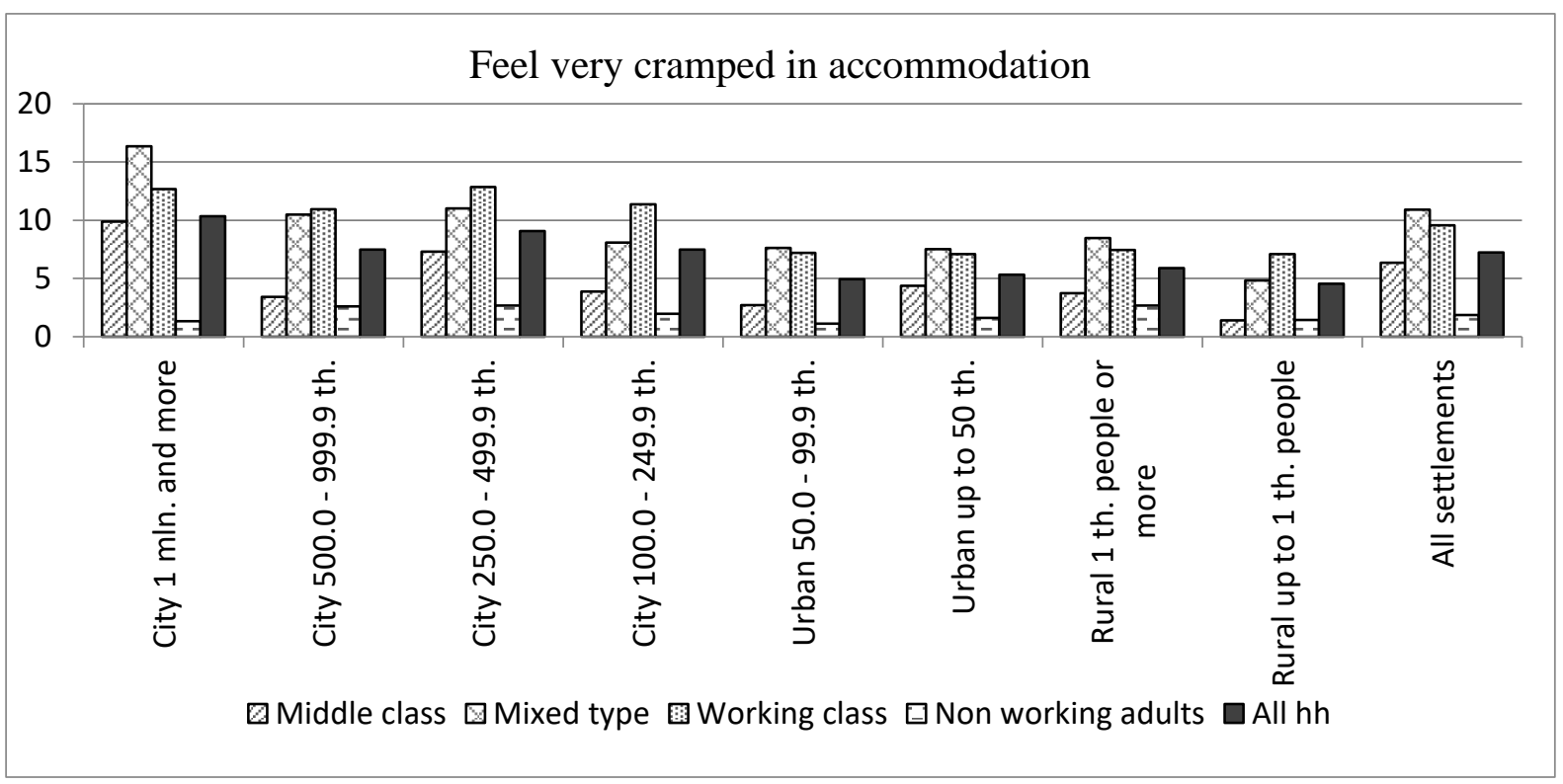

Source: Calculations on GKS-KOUZH-2016 data

At the end of this sub-section we consider the dimension of housing comfort related to the provision of housing amenities and durable goods. The most common communal convenience is electricity. It is accessible for almost all respondents of the SDMR. There are several households 'without electricity' in the 2007 data, but other records demonstrate that these people watch TV and use other electric appliances, which would be impossible to do with no electric supply. Thus, we consider these cases as record errors. See Figure 11. About $60 \%$ of housing is equipped with basic communal facilities: running cold water, sewage disposal, running hot water or gas heating for water, central heating or individual gas heating. 
Figure 11 - Housing equipped by communal facilities by strata, \%

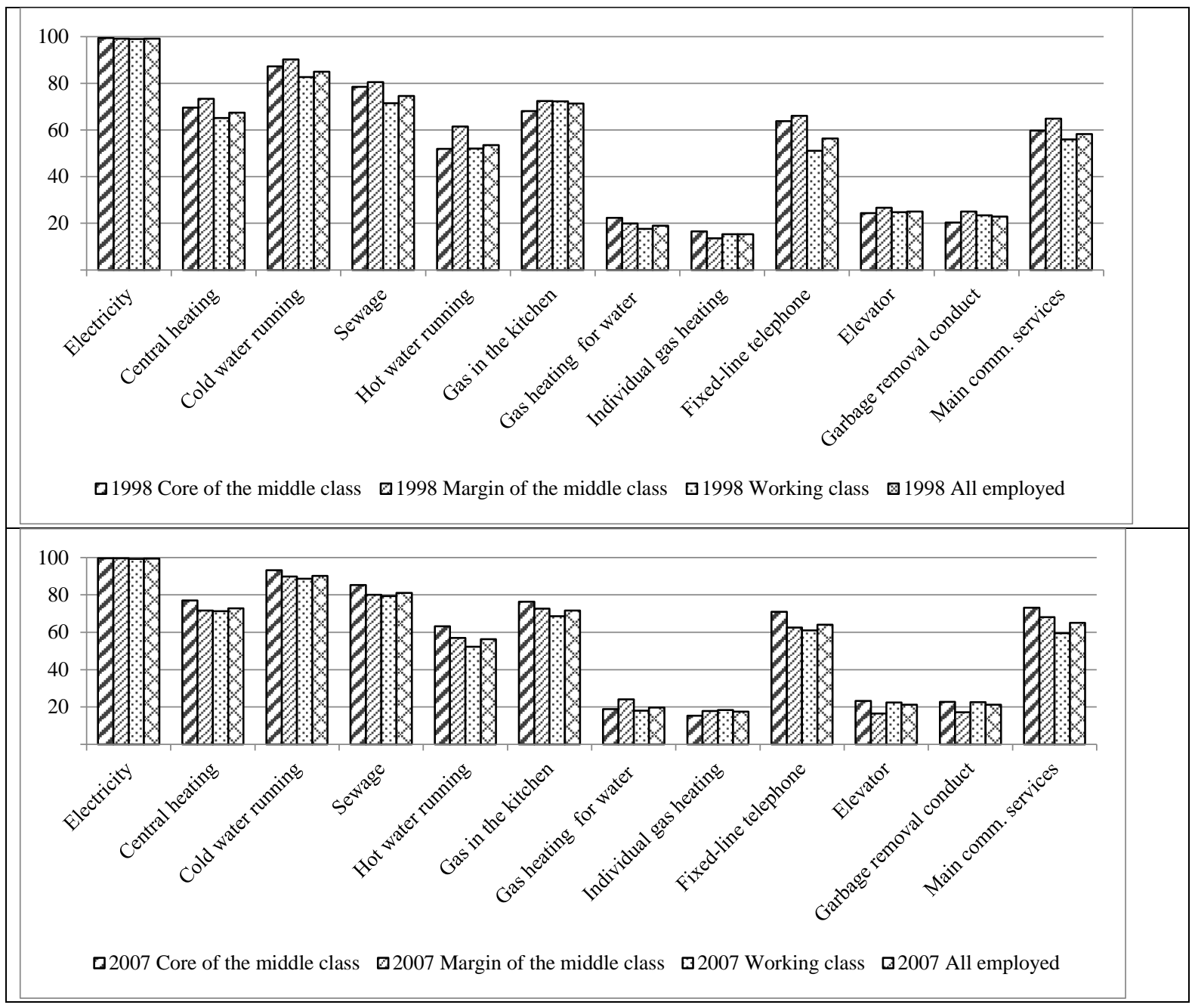

As argued above, class difference in terms of the size of housing is small. Yet, as far as home utilities are concerned (see Table 3), in 1998 the margin of the middle class lived in the most comfortable houses or apartments. For the core of the middle class, the share of housing with access to the main communal services was $60 \%$ in 1998 and $73 \%$ in 2007 . The working class lived in less comfortable conditions: $56 \%$ of its representatives in 1998 and $60 \%$ in 2007 lived in homes equipped with all the basic communal facilities. The difference has increased, but can we attribute it to the manifestation of class privilege? Access to basic utilities is largely an endogenous characteristic. As we have demonstrated before, the housing stock in large cities mainly consists of apartment buildings, which are connected to utilities. On the contrary, central heating is rare and impractical in rural areas. Since $24 \%$ of the working class lives in rural areas and $76 \%$ reside in cities and towns, but only $17-19 \%$ of the middle class live in villages and $81-83 \%$ in urban settlements, it is the urban/rural distinction that fundamentally explains the unequal class assess to housing utilities. 
Table 3 - Housing equipped with communal facilities by strata, \%

\begin{tabular}{|c|c|c|c|c|c|c|c|c|}
\hline & \multicolumn{4}{|l|}{1998} & \multicolumn{4}{|l|}{2007} \\
\hline & $\begin{array}{l}\text { Core of } \\
\text { the } \\
\text { middle } \\
\text { class }\end{array}$ & $\begin{array}{l}\text { Margin } \\
\text { of the } \\
\text { middle } \\
\text { class }\end{array}$ & $\begin{array}{l}\text { Working } \\
\text { class }\end{array}$ & $\begin{array}{l}\text { All } \\
\text { employed }\end{array}$ & $\begin{array}{l}\text { Core of } \\
\text { the } \\
\text { middle } \\
\text { class }\end{array}$ & $\begin{array}{l}\text { Margin } \\
\text { of the } \\
\text { middle } \\
\text { class }\end{array}$ & $\begin{array}{l}\text { Working } \\
\text { class }\end{array}$ & $\begin{array}{l}\text { All } \\
\text { employed }\end{array}$ \\
\hline Electricity & 99 & 99 & 99 & 99 & 100 & 100 & 99 & 100 \\
\hline Central heating & 70 & 73 & 65 & 67 & 77 & 72 & 71 & 73 \\
\hline Cold water running & 87 & 90 & 83 & 85 & 93 & 90 & 89 & 90 \\
\hline Sewage & 79 & 81 & 71 & 75 & 85 & 80 & 79 & 81 \\
\hline Hot water running & 52 & 61 & 52 & 53 & 63 & 57 & 52 & 56 \\
\hline Gas in the kitchen & 68 & 72 & 72 & 71 & 76 & 73 & 69 & 72 \\
\hline Gas heating for water & 22 & 20 & 18 & 19 & 19 & 24 & 18 & 20 \\
\hline Individual gas heating & 17 & 14 & 15 & 15 & 15 & 18 & 18 & 17 \\
\hline Fixed-line telephone & 64 & 66 & 51 & 56 & 71 & 63 & 61 & 64 \\
\hline Elevator & 24 & 27 & 25 & 25 & 23 & 16 & 22 & 21 \\
\hline Garbage removal & 20 & 25 & 23 & 23 & 23 & 17 & 23 & 21 \\
\hline Cable TV & & & & & 31 & 26 & 25 & 27 \\
\hline Internet & & & & & 23 & 13 & 10 & 14 \\
\hline Main communal services & 60 & 65 & 56 & 58 & 73 & 68 & 60 & 65 \\
\hline
\end{tabular}

Again, elevators and garbage removal are strongly associated with living in a block of flats there is no great difference between middle- and working-class housing in the equipment by these communal facilities. At the same time, as Table 4 illustrates, the use of Internet and cable TV display high class differences: $23 \%$ of the core of the middle class and $10 \%$ of the working class have the Internet at home. Cable TV is available to $31 \%$ of the core of the middle class and $25 \%$ of the working class. Equally, as far as available household appliances, equipment, and durable goods are concerned, it can be observed that a more modern and high-tech life style is a characteristic of the middle class. This supports the findings of Li et al (2013: 360361) that the middle class is widely involved in computer usage. According to the SDMR-2007 data, $54 \%$ of the core of the middle have computers, $47 \%$ have hi-fis, $49 \%$ have microwaves, and $90 \%$ have mobile phones. Among the working class the shares are lower: $34 \%$ for computers, $34 \%$ for hi-fis, $38 \%$ for microwaves, and $77 \%$ for mobile phones.

Table 4 - Household appliances, equipment and property, \% by strata

\begin{tabular}{|c|c|c|c|c|c|c|c|c|c|c|}
\hline & \multicolumn{5}{|l|}{1998} & \multicolumn{5}{|l|}{2007} \\
\hline & $\begin{array}{l}\text { Core of } \\
\text { the } \\
\text { middle } \\
\text { class }\end{array}$ & $\begin{array}{l}\text { Margin of } \\
\text { the middle } \\
\text { class }\end{array}$ & $\begin{array}{l}\text { Wor } \\
\text { king } \\
\text { class } \\
\end{array}$ & $\begin{array}{l}\text { All } \\
\text { empl } \\
\text { oyed } \\
\end{array}$ & $\begin{array}{l}\text { Core of } \\
\text { the } \\
\text { middle } \\
\text { class }\end{array}$ & $\begin{array}{l}\text { Core of } \\
\text { the } \\
\text { middle } \\
\text { class }\end{array}$ & $\begin{array}{l}\text { Margin of } \\
\text { the middle } \\
\text { class }\end{array}$ & $\begin{array}{l}\text { Wor } \\
\text { king } \\
\text { class } \\
\end{array}$ & $\begin{array}{l}\text { All } \\
\text { empl } \\
\text { oyed }\end{array}$ & $\begin{array}{l}\text { Core of } \\
\text { the } \\
\text { middle } \\
\text { class }\end{array}$ \\
\hline TV & 98 & 98 & 97 & 97 & 97 & 98 & 97 & 98 & 98 & 98 \\
\hline $\begin{array}{l}\text { Satellite } \\
\text { TV }\end{array}$ & 0 & 0 & 0 & 0 & 0 & 10 & 3 & 2 & 4 & 4 \\
\hline $\begin{array}{l}\text { Video or } \\
\text { DVD tape } \\
\text { recorder }\end{array}$ & 52 & 51 & 47 & 49 & 40 & 76 & 71 & 64 & 69 & 59 \\
\hline Camcorder & 8 & 5 & 2 & 4 & 3 & 32 & 20 & 17 & 22 & 18 \\
\hline Hi-fi & 24 & 28 & 19 & 22 & 18 & 47 & 37 & 34 & 38 & 31 \\
\hline $\begin{array}{l}\text { Mobile } \\
\text { phone }\end{array}$ & 3 & 2 & 1 & 2 & 1 & 90 & 81 & 77 & 81 & 71 \\
\hline Computer & 8 & 5 & 3 & 5 & 4 & 54 & 37 & 34 & 40 & 33 \\
\hline
\end{tabular}




\begin{tabular}{|l|l|l|l|l|l|l|l|l|l|l|}
$\begin{array}{l}\text { Dishwashe } \\
\mathrm{r}\end{array}$ & 0 & 0 & 0 & 0 & 0 & 3 & 2 & 2 & 2 & 2 \\
\hline $\begin{array}{l}\text { Microwav } \\
\text { e }\end{array}$ & 11 & 9 & 4 & 6 & 5 & 49 & 43 & 38 & 42 & 36 \\
\hline $\begin{array}{l}\text { Washing } \\
\text { machine }\end{array}$ & 88 & 84 & 85 & 85 & 81 & 89 & 86 & 82 & 85 & 82 \\
\hline $\begin{array}{l}\text { Refrigerat } \\
\text { or }\end{array}$ & 97 & 96 & 97 & 97 & 96 & 96 & 95 & 94 & 95 & 94 \\
\hline $\begin{array}{l}\text { Vacuum } \\
\text { cleaner }\end{array}$ & 86 & 77 & 78 & 80 & 74 & 91 & 84 & 82 & 85 & 80 \\
\hline $\begin{array}{l}\text { Good } \\
\text { furniture }\end{array}$ & 34 & 28 & 26 & 29 & 24 & 53 & 41 & 41 & 44 & 39 \\
\hline $\begin{array}{l}\text { Summer } \\
\text { cottage }\end{array}$ & 38 & 33 & 24 & 29 & 27 & 30 & 25 & 23 & 25 & 24 \\
\hline Apartment & 45 & 43 & 35 & 39 & 38 & 66 & 65 & 64 & 65 & 63 \\
\hline Car & 49 & 40 & 34 & 38 & 32 & 53 & 45 & 39 & 44 & 36 \\
\hline
\end{tabular}

Table 4 also shows that the representatives of the upper strata more often own expensive items of property such as a car or a summer cottage. In $200753 \%$ of middle-class people owned cars, and $30 \%$ dachas. For the working-class stratum, the share of car-owners was significantly lower, at $39 \%$. Only $23 \%$ of working-class families owned a summer cottage. Yet, the class difference was negligible with respect to the most basic household appliances, including washing machines, refrigerators, and TVs.

To summarize, our analysis concerning the objective and subjective characteristics of the housing conditions of the Russian households by class reveals that the middle class is somewhat better-housed compared to the working class in the objective (having a housing unit of their own and availability of the housing space per person), but particularly, in the subjective (feeling a lack of space and the self-reported physical state of the housing unit) senses. The provision of most basic utilities is more primarily determined by the settlement type than by household class characteristics. Nonetheless, the middle class is more likely to own modern goods and services, such as computers, and have Internet access, as well as expensive items such as cars and dachas.

\section{Tenure structure, policy impact, market practices, and attitudes}

In this section, we consider aspects of the housing situation of the Russian middle class as the structure of housing ownership, including ownership in different types of settlements, and the uptake of the Maternity Capital. We will also consider the strategies used by Russian families belonging to different classes for changing their housing conditions. Our particular interest here is the question of to what extent different classes within the Russian society have internalized market practices. We also ask about the discipline with which different groups pay their utility bills and the attitudes they have towards the housing sphere.

The GKS-KOUZH-2016 data allows us to judge the extent of home ownership among different classes. The highest proportion of owners is among non-working households. Most of these are pensioners (Figure 12). There is a high level of home ownership in the mixed group, and $86 \%$ of the working class and $88 \%$ of the middle class own their homes. The difference between the classes, however, is not great. 
Figure 12 - Household ownership of main dwelling by strata, \%

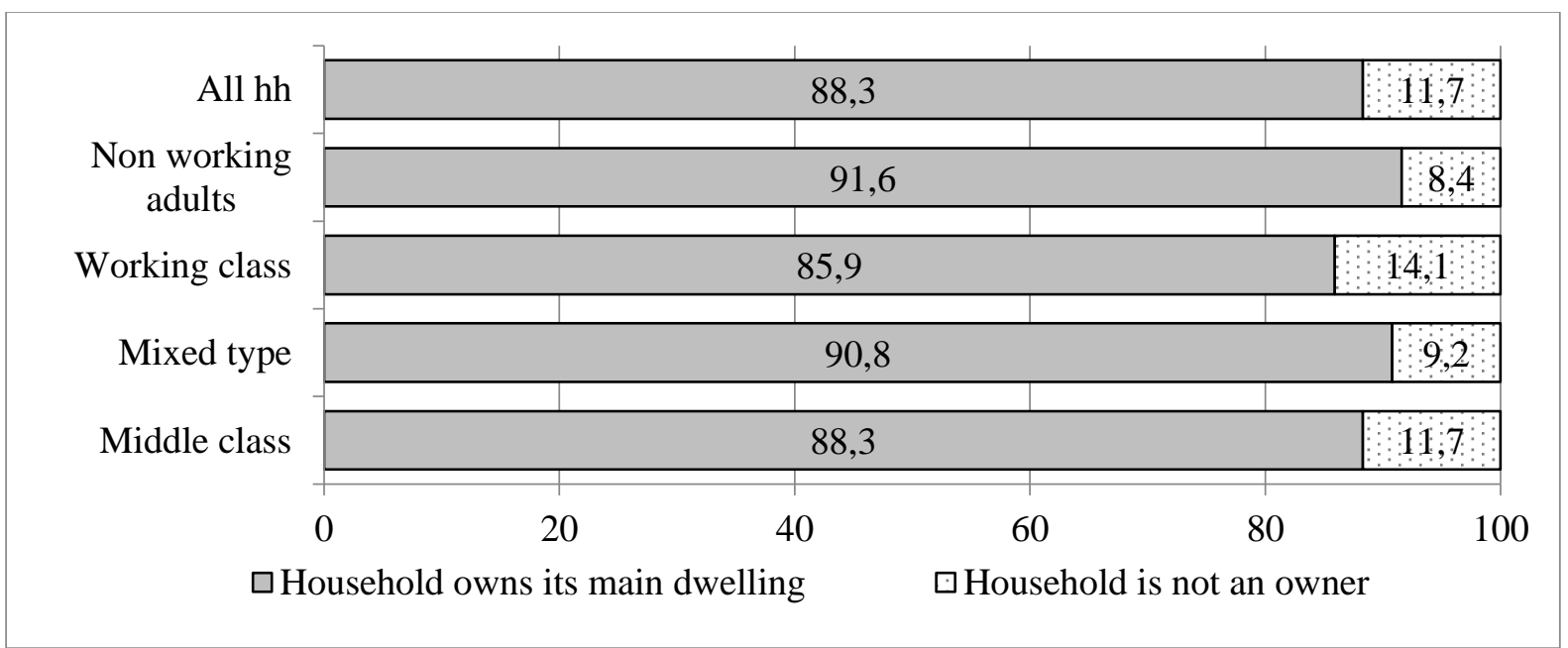

Source: Calculations on GKS-KOUZH-2016 data

On average $12 \%$ of middle-class households and $14 \%$ of the working class do not own their dwellings. Across different types of settlements, home ownership among the middle class is higher than that of the working class by 1-6 percentage points. See Figure 13.

Figure 13 - Non-ownership of dwellings by strata and type of settlement, \%

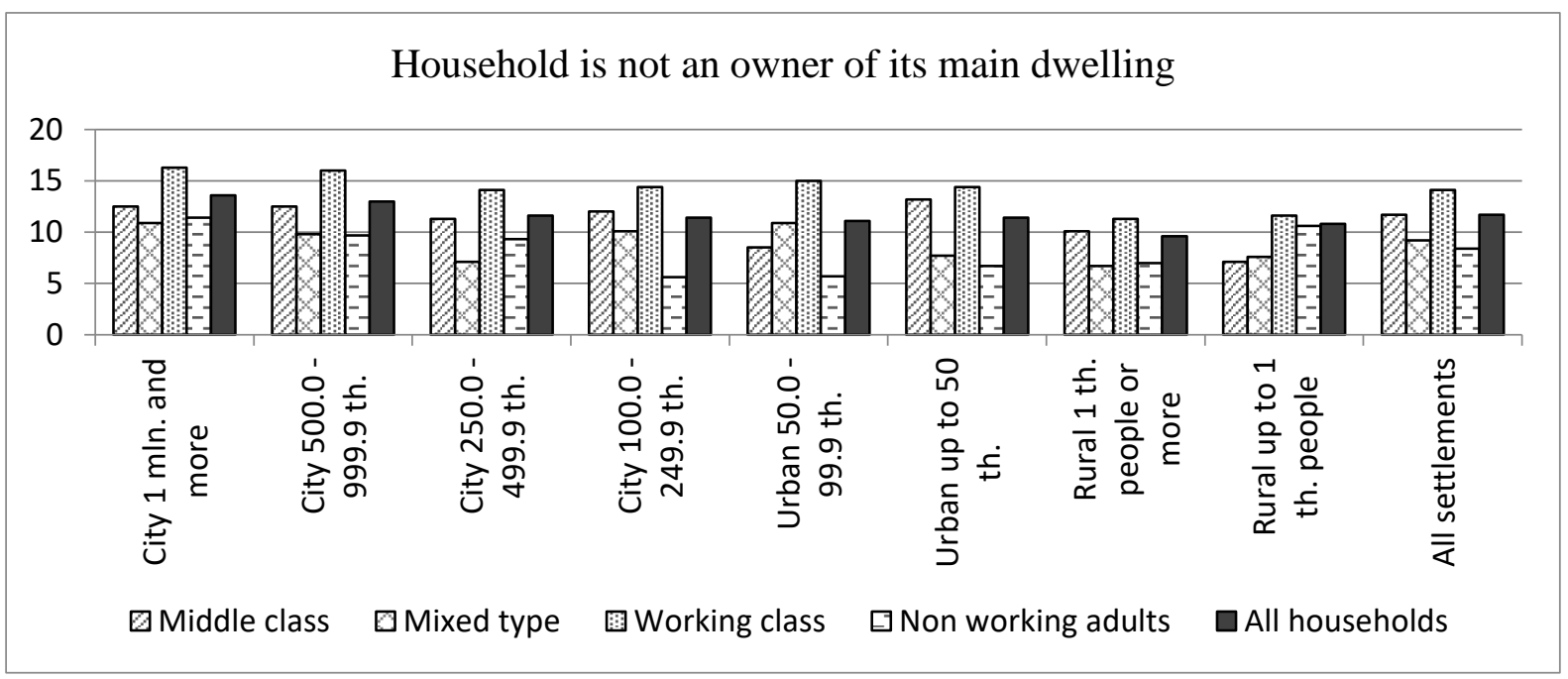

Source: Calculations on GKS-KOUZH-2016 data

From home ownership, we move to the Maternity Capital policy, which many Russian families have used to move to a new house or flat. Did the respondents of the SDMR survey receive Maternity Capital and is there any specificity by strata? The distribution of Maternity Capital, 
as argued earlier in this chapter, is a policy with no obvious attachment to a recipient's class position. Every mother, as a citizen of the Russian Federation, has a right to receive the benefit if she gives birth to a second child during the period of the programme. The first reading of this data, however, may suggest that this policy, nonetheless, favours middle-class families. While about $18 \%$ of all working people in SDMR-2015 claimed that their household received a Maternity Capital certificate, the figures for the core and margin of the middle class were over $20 \%$, whereas for the working class this was only $15 \%$. Given that the policy is not classtargeted, the only explanation for such a difference may lie in the lesser eligibility of the working-class sub-sample. Consideration of the age differences in the sub-groups offers a plausible explanation. Indeed, the working-class stratum is younger than the middle class (see Figure 8) and 27\% of the working-class people in the SDMR-2015 are under 30. For some of them the birth of a second child, and, thus, the Maternity Capital entitlement, are things to come.

Figure 14 - Age distribution by strata, \%

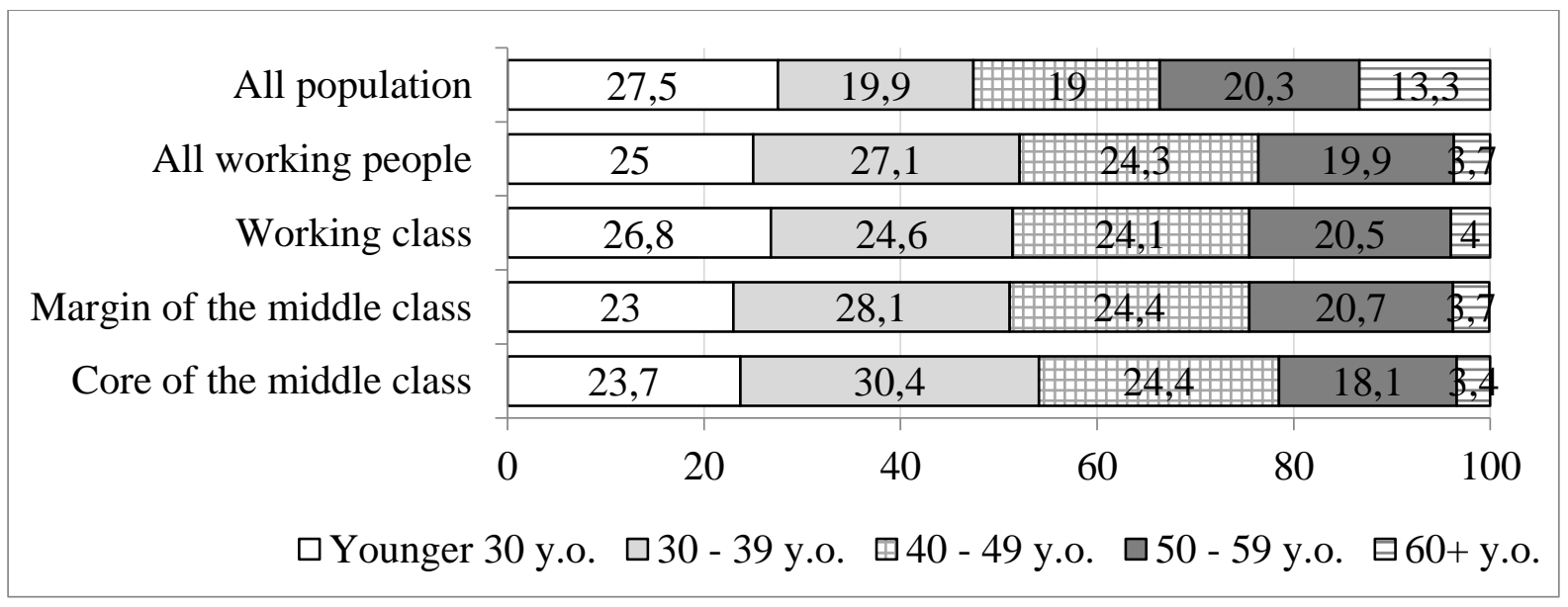

Source: Calculations on SDMR-2015 data

As argued in our policy survey in Section 1, Maternity Capital allows families with children to move to more suitable housing. However, the need and intention to move cannot be considered as exclusive to families with children. How many Russian families by strata have the intent to move house? It was already noted that as a rule, mixed households tend to experience a lack of housing space and thus have a greater need for more spacious housing. Figure 15 demonstrates that this indeed is the case, while in both middle- and working-class strata the intent to change housing conditions is the same, $16 \%$. On average the share of households who intend to move makes up only half of those facing some or an acute lack of housing space. This is true for the working-class and mixed families. The middle class shows more active intentions to move compared to the rest of this stratum. 
Figure 15 - Assessment of physical condition of the dwelling by strata and intention to change housing, \%

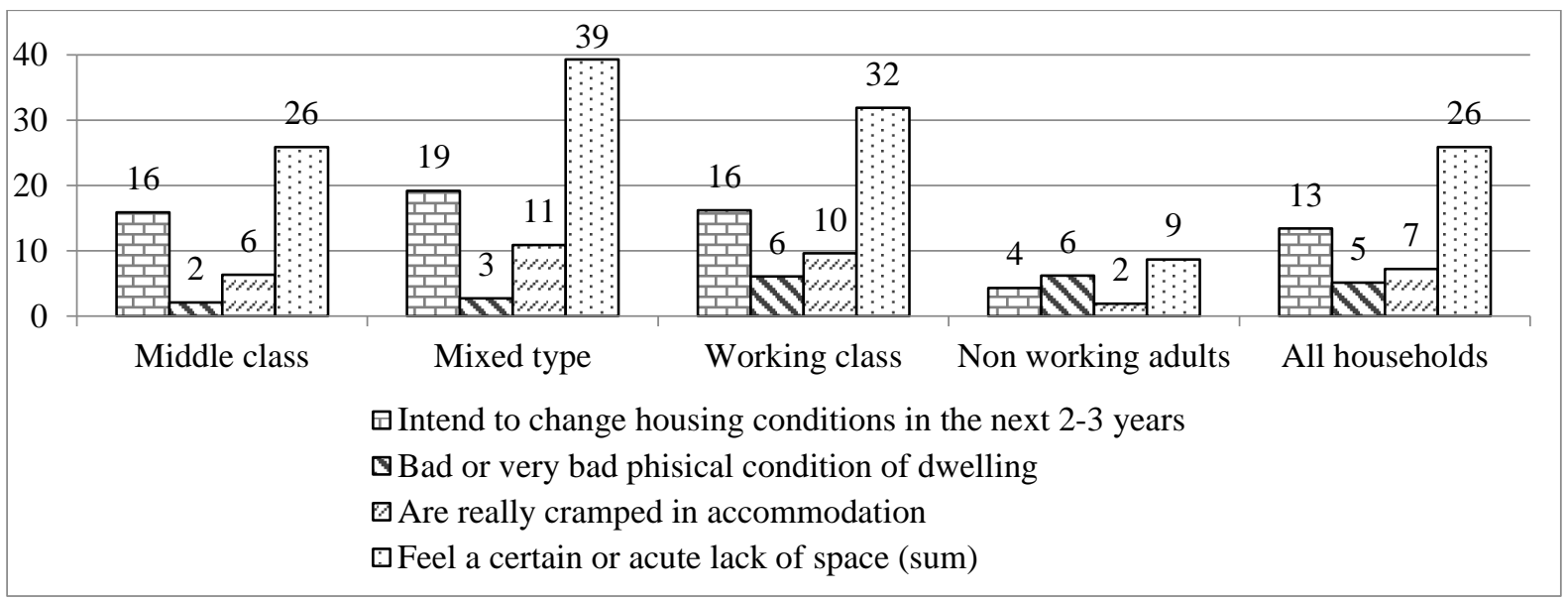

Source: Calculations on GKS-KOUZH-2016 data

The strategies which different classes among the Russian people consider using in connection to their plans to move to a new house are worth noting. Analysis of these strategies offers a way to ascertain attitudes towards market practices as well as the reliance on government welfare among Russian people. Different strategies that strata intend to use in the next two to three years are presented in Table 5. The middle class is twice as likely to be planning to move into new housing already under construction (3.5\% of the middle class and $1.8 \%$ working class) and more likely to be planning a house purchase $(7.2 \%$ of the middle class and $5.2 \%$ of the working class). A significantly smaller percentage of Russians rely on state social assistance in improving their housing situations. Only $0.9 \%$ of the middle class and $1.3 \%$ of the working class had the intention to join a housing waiting list in 2016. Another $0.3 \%$ of the middle class and $0.6 \%$ of the working class expected to receive new accommodation allocated according to the demolition programmes. Although the numbers are not high, they demonstrate that housing strategies involving state social assistance are more prominent among the working class. The middle class, on the contrary, is more likely to rely on market mechanisms.

Table 5 - Strategies to improve housing conditions in the next 2-3 years by strata, \%

\begin{tabular}{|c|c|c|c|c|c|}
\hline & $\begin{array}{c}\text { Middle } \\
\text { class }\end{array}$ & $\begin{array}{c}\text { Mixed } \\
\text { type }\end{array}$ & $\begin{array}{c}\text { Working } \\
\text { class }\end{array}$ & $\begin{array}{l}\text { Non-working } \\
\text { adults }\end{array}$ & All hh \\
\hline $\begin{array}{l}\text { Intend to change housing conditions in the next } \\
2-3 \text { years using the following strategies: }\end{array}$ & 15.9 & 19.2 & 16.2 & 4.3 & 13.4 \\
\hline $\begin{array}{r}\text { Plan to move into new housing which is already } \\
\text { under construction }\end{array}$ & 3.5 & 3.6 & 1.8 & 0.2 & 1.9 \\
\hline $\begin{array}{l}\text { Plan to apply to be placed on a housing waiting } \\
\text { list }\end{array}$ & 0.9 & 1.4 & 1.3 & 0.3 & 1.0 \\
\hline $\begin{array}{r}\begin{array}{r}\text { Expect to receive new housing according to the } \\
\text { demolition programme }\end{array} \\
\end{array}$ & 0.3 & 0.4 & 0.6 & 0.4 & 0.5 \\
\hline $\begin{array}{r}\text { Plan to buy / build more housing (including } \\
\text { exchange) }\end{array}$ & 7.2 & 7.9 & 5.2 & 0.5 & 4.6 \\
\hline Plan to rent house / apartment & 0.3 & 0.6 & 0.6 & 0.2 & 0.5 \\
\hline $\begin{array}{r}\begin{array}{r}\text { Plan to improve housing conditions using other } \\
\text { strategies }\end{array} \\
\end{array}$ & 3.6 & 5.1 & 6.4 & 2.6 & 4.8 \\
\hline
\end{tabular}

Source: Calculations on GKS-KOUZH-2016 data 
It can also be pointed out that the intention to buy or build a new home, which involves selling the current apartment or house, is a rather 'natural' market-based strategy to improve housing conditions across all strata. Nearly half of all those intending to move among the middle class $(7.2 \%)$ and a lesser proportion - about a third - of the working class (5.2\%) chose this strategy. Renting a house or an apartment remains rather unpopular $-0.3 \%$ among middle-class and $0.6 \%$ among working-class households.

As far as the financing of a new house purchase was concerned, for those intent on moving in the next two to three years (those expecting to receive social housing or an inheritance are not included) the results are shown in Table 6 . Among the $16 \%$ who had the intention to improve their housing conditions, a quarter of middle-class households (4\%) and only half of that figure for working-class families (2\%) were planning to take out a mortgage. The figure was higher for mixed households. Nearly a third of those planning to move to new accommodation $(5 \%)$ in the mixed households category were considering a mortgage loan. Plans to use Maternity Capital were approximately similar for the middle and working class (under 1.5\%). At the same time, the middle class relied more on their own capital and savings (3\%) compared to the working class (2\%). Thus, based on this data we would argue that the Russian middle class to a certain degree has started to display typical middle-class behaviour in relation to finance, which includes financial prudency, savings, and the use of credit.

Table 6 - Intended sources of finance for the purchase/construction of a house/flat in the next 2-3 years by strata, $\%$

\begin{tabular}{|l|c|c|c|c|c|}
\hline & $\begin{array}{c}\text { Middle } \\
\text { class }\end{array}$ & $\begin{array}{c}\text { Mixed } \\
\text { type }\end{array}$ & $\begin{array}{c}\text { Working } \\
\text { class }\end{array}$ & $\begin{array}{c}\text { Non- } \\
\text { working } \\
\text { adults }\end{array}$ & All hh \\
\hline Sale of existing housing to buy another & 3.1 & 2.7 & 1.7 & 0.2 & 1.6 \\
\hline Mortgage loan & 3.8 & 4.6 & 2.3 & 0.1 & 2.2 \\
\hline Maternity Capital & 1.3 & 1.6 & 1.4 & 0.1 & 1.1 \\
\hline Means of military accumulative system & 0.1 & 0.0 & 0.1 & 0.0 & 0.0 \\
\hline Housing subsidy & 0.3 & 0.2 & 0.2 & 0.0 & 0.2 \\
\hline Other sources (including own funds) & 2.9 & 2.9 & 1.9 & 0.2 & 1.7 \\
\hline Hard to answer & 0.1 & 0.0 & 0.0 & 0.0 & 0.0 \\
\hline
\end{tabular}

Source: Calculations on GKS-KOUZH-2016 data

This observation is further confirmed when we consider housing development behaviour. The GKS-KOUZH-2016 survey allows an examination of the practice of new housing development. At the time of the GKS-KOUZH-2016 survey, 3\% of the middle class were involved in the construction of an apartment and $1 \%$ were building a detached house (Table 7). The working class, by contrast, was less likely to be involved in construction. Then, $2 \%$ of the middle class took out credit loans; for the working class the figure was $0.8 \%$. From Table 7 it is also evident that the middle class was more relying on their own capital or savings $(3 \%)$, while in terms of the Maternity Capital investment in construction there was no great difference between strata. 
Table 7 - Sources of funding for current construction of a home/apartment by strata, \%

\begin{tabular}{|r|c|c|c|c|c|}
\hline & $\begin{array}{c}\text { Middle } \\
\text { class }\end{array}$ & $\begin{array}{c}\text { Mixed } \\
\text { type }\end{array}$ & $\begin{array}{c}\text { Working } \\
\text { class }\end{array}$ & $\begin{array}{c}\text { Non- } \\
\text { working } \\
\text { adults }\end{array}$ & All hh \\
\hline New construction of: & & & & & \\
\hline apartment in an apartment building & 2.5 & 2.0 & 0.6 & 0.1 & 0.9 \\
\hline residential house (part of house) & 1.2 & 2.2 & 1.3 & 0.2 & 1.1 \\
\hline house on garden (country) plot, 'dacha' & 0.9 & 1.1 & 0.4 & 0.2 & 0.5 \\
\hline Fother place for permanent (seasonal) residence & 0.1 & 0.1 & 0.1 & 0.0 & 0.1 \\
\hline Finance for construction: & & & & & \\
\hline Maternity Capital & 2.0 & 2.3 & 0.8 & 0.1 & 1.0 \\
\hline savings and/or other capital & 2.9 & 0.9 & 0.5 & 0.1 & 0.5 \\
\hline
\end{tabular}

Source: Calculations on GKS-KOUZH-2016 data

To summarize what has been said so far in relation to the intent to improve the housing situation, while market practices certainly appear as the most common strategy across the board, they also represent a more pronounced strategy among the middle class. We, therefore, would generally support the argument put forward in Gunko et al. (2018: 300) that most homebuyers are middle class, yet with one qualification. This may be the case in the city of Moscow where Gunko et al.'s study was conducted. Across the entire country, however, representatives of all strata purchase and build new housing. Still, there are more representatives of the middle class among those who buy and build housing.

Another factor which we consider below and which both demonstrates the proliferation of market practices among different strata, as well as being an indication of their material wellbeing, is payments for housing and utility services. The middle class again emerges as a more disciplined group. About $15 \%$ of all households said that they had missed payments for housing and communal services at one time or another due to lack of income (see Figure 16). Among the middle class, $9 \%$ reported that they had had such arrears, including 5\% who did not pay on time twice or more. For the working class the problem was significantly more severe: $18 \%$ failed to pay on time at one point, including $11 \%$ who had arrears at least twice during the last year before the survey.

Figure 16 - Arrears in payment of housing and communal services due to lack of money by strata, $\%$

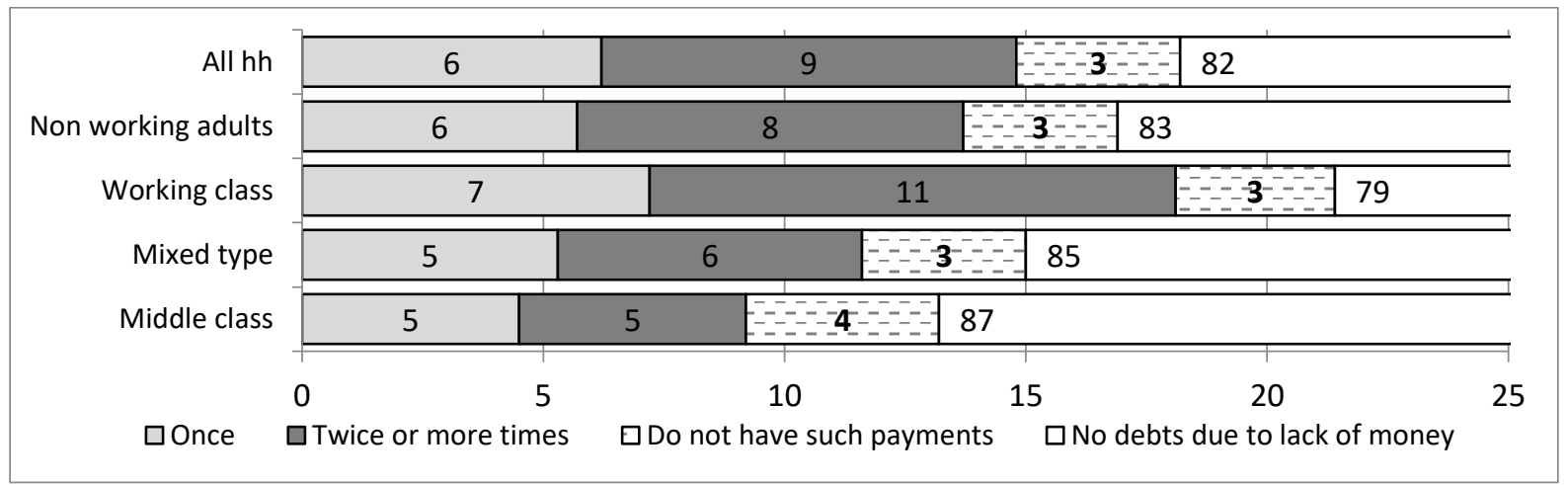

Source: Calculations on GKS-KOUZH-2016 data

[Type here] 
Another category of housing payments is rent and mortgage payments. These are not as prominent in our sample: $87 \%$ of the working class and $86 \%$ of the middle class did not have such payments at all (Figure 17). Nevertheless, $2.4 \%$ of working-class families had arrears in rent and mortgage payments in the year preceding the survey. Among the middle class, at the same time, $1.6 \%$ households failed to pay on time. ${ }^{\mathrm{x}}$

Figure 17 - Arrears in rent and mortgage payments for the main home due to lack of money by strata, $\%$

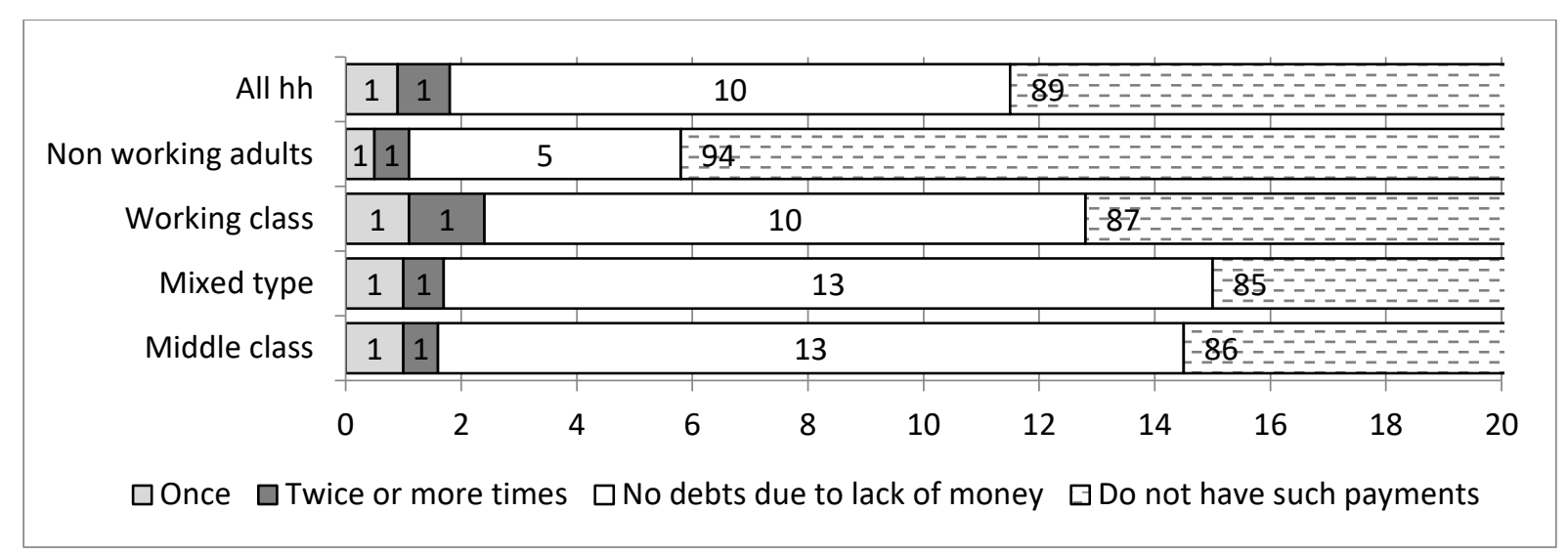

Source: Calculations on GKS-KOUZH-2016 data

We conclude this section with an analysis of the attitudes held by the different strata among Russian society towards the housing sphere. The SDMR survey data in their three waves of 1998-2007-2015 presents a rather complex picture. At first glance, the results presented in Figures 18 and 19 are striking. The SDMR data demonstrate that since 1998 - while about 5\% of SDMR respondents found this question difficult to answer - most people in all strata (88$92 \%$ ) continued to believe that the authorities should be responsible for providing housing and communal services. There are notable developments in the data too. During the considered period, the area of the regional authority's responsibility grew from $8 \%$ to $20 \%$ of the opinion. Federal responsibility increased from $43 \%$ to $50 \%$ of the responses in 2007 but decreased to $39 \%$ in 2015 . In the 2000 s, the working class was relying slightly more on the federal authorities and less on the municipalities than the middle class. Nevertheless, municipal responsibility was the most popular answer for all strata to the question about communal services provision. Overall, distinctions between strata were not crucial. Thus, the majority of Russians, by and large regardless of their class position, appeared to entrust the state and its different administrative layers with providing housing and communal services. Personal responsibility and private firms, as shown in Figure 19, were mentioned by a minority of respondents. 
Figure 18 - How many strata representatives think in 1998-2007-2015 that local, regional or federal levels of authority should run communal services, $\%$

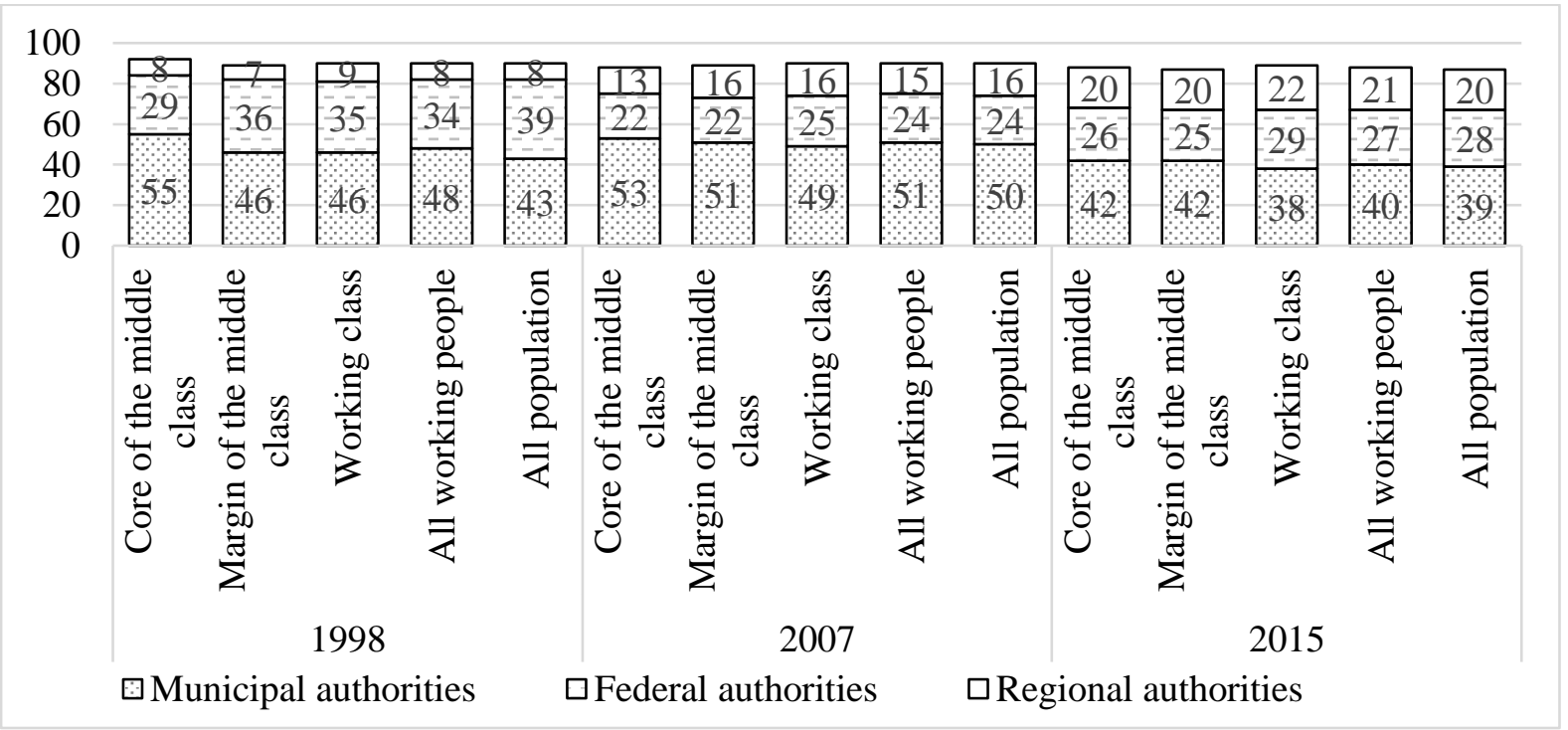

Figure 19 - How many strata representatives think that citizens themselves or private companies should run communal services in 1998-2007-2015, \%

7

0

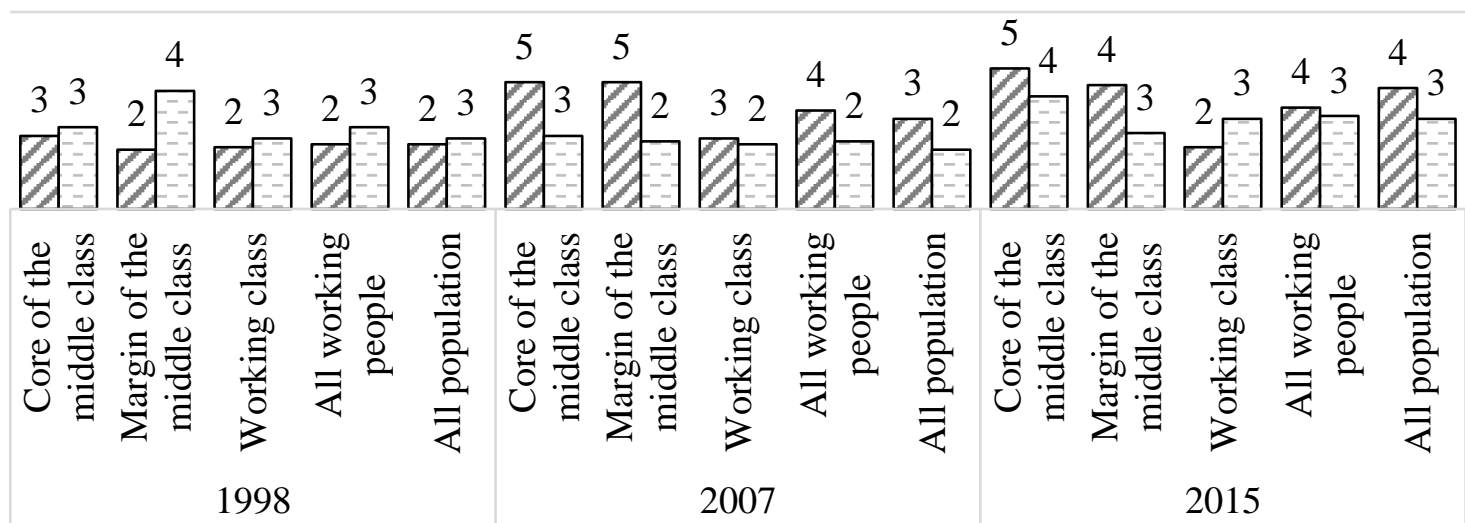

口Citizens $\quad \boxminus$ Private firms

This distribution of answers seems to offer support for a stereotypical perception of Russians as holding paternalistic values, distrusting the markets and reluctant to take on personal responsibility. These attitudes could, moreover, be attributed to the legacy of the socialist welfare model and the post-Soviet transition in the 1990s when, as explained in Section 1, the public was charged a mere fraction of their housing and utility costs. At the time of writing, this interpretation may be reinforced by such occurrences as the pensioners' movement observed in some locations in Siberia peculiarly termed the 'Born in the USSR' trade union.' ${ }^{\mathrm{x} i}$ The organizers of this movement claimed that its members abide by Soviet laws, which made them exempt from paying commercial prices for utilities and housing services. Although not

[Type here] 
constituting a mass movement by any means, such instances suggest that some groups among the Russian public may in fact still expect the state to provide housing and utilities at negligible prices.

We, however, would like to challenge this view, first by pointing out that such an interpretation would stand in stark contrast to what has been demonstrated earlier in this section. Russian people pay their maintenance and utility bills in full, even if with occasional delays, which were rare in any case at only $15 \%$ of observations. Across all groups, households were more reliant on market mechanisms when considering improving their housing conditions. The expectations that state social assistance could help them out in this were significantly lower. If so, what is going on with the survey data?

In solving this puzzle, it is important to point to the difference in the question formulation between different waves of the SDMR survey. In the 1998 questionnaire, the question referred primarily to the responsibility for 'housing' among other services. In 2007 and in 2015 the question was: 'Who should run communal services?' i.e. mainly about the provision of communal services. The common attitude among the majority of the Russian public that they prefer the state to provide various social services is well acknowledged in the literature (for instance Kulmala et al. 2014). However, as to why Russian people hold such attitudes, we suggest that in respect of housing and utility services the respondents might have interpreted the question primarily in terms of responsibility for monitoring the quality and guaranteeing the prices of service provision.

The distribution of answers between the levels of state authority also speaks in favour of this interpretation. In Russia, opinion polls continually show that the most trusted institution in the country is the President. ${ }^{\text {xii }}$ However, as far as housing is concerned most people put their trust in the municipal level, whereas the share of regional trust has increased at the expense of both the federal and municipal trust levels. The regional level may be seen as increasingly important because it can provide checks over municipal behaviour in terms of utilities and housing services provision more effectively than the federal authorities. There have been cases, particularly around the time of the third wave of the SDMR in 2015, when municipalities put up communal charges at rates exceeding inflation, in order to ease the pressure on their budgets. Such instances provoked popular protests, as for example in Novosibirsk, where the public demanded the regional governor put pressure on the misbehaving municipalities. ${ }^{x i i}$ Given that the growth of housing and utility charges in the mid-2010 was outstripping price growth for other goods and services, it is perhaps unsurprising that these charges represented an area of a particular concern for the public (see Sinel'nikov-Murylev and Radygin 2018: 326-333).

\section{Conclusion}

The first part of the chapter examined Russian housing policy since the early 1990s. It was argued that this policy was dominated by the liberal approach, which aimed to increase personal responsibility for one's welfare, including housing and utility services. This approach, 
nevertheless, was also complemented by a group of measures to support vulnerable groups and particularly families with children. However, there was no apparent targeting of policies to specific class groups. The analysis of the policy initiatives in the first section laid the basis for the examination of the survey data in the second part of the chapter.

The central question for this part was what it means to be middle class in contemporary Russia in terms of the housing situation. Our analysis has shown that in certain areas - particularly in the quality of housing, the use of credit, constructing different types of housing and buying housing, the use of savings and capital (mostly, existing housing) to finance new house purchases - a difference between classes was observed. The middle class was also more disciplined in making timely payments for housing services. The inequality between classes, at the same time, was less pronounced in terms of what we defined as the 'objective' quality of housing, ownership, the use of Maternity Capital, and attitudes to housing. The difference in housing between urban and rural areas was determined by labour market conditions rather than attributable to class disparities. Overall, then, while the liberalization of housing was the objective of housing policy, as argued in Section 1, the inequality that is usually associated with neo-liberalism increased insignificantly. This is due to the legacy of housing provision during the socialist period and the policy of free housing privatization, which was not classtargeted. Low levels of housing mobility in Russia ${ }^{\text {xiv }}$ further helped to conserve a relatively egalitarian housing structure. Nonetheless, emerging class differences, especially in terms of financial behaviour and involvement in new housing development, can be regarded as important. Therefore, we conclude that while housing privatization was the central policy measure introduced in the 1990s that defined the development of the Russian housing sphere for decades, class structuration in this sphere is emerging, a trend which may be expected to deepen with time as the legacy of housing privatization falls back into history.

\section{References}

Artem'ev, M. 2019. Prestupnaya pospeshnost': chem obernulas' privatisatsiya kvartir, Forbes.ru, 14 January, 16:07.

Attwood, L. 2010. Gender and Housing in Soviet Russia: Private Life in a Public Space, Manchester: Manchester University Press.

Bogomolova, T. and Cherkashina, T. 2018. Institutsional'no-ekonomicheskiy kontekst formirovaniya nefinansovogo bogatstva rossiyskikh domokhozhiaystv: ot privatizatsii $\mathrm{k}$ priobreteniyu, Mir Rossii, 27(2): 62-89.

Burdyak, A. 2017. Housing expenditures, purchase and rental of residential properties in Russia's regions, Russian Economic Development, 24(5): 75-79.

Burdyak, A., Lyashok, V., and Maleva, T. 2018. Sotsial'no-ekonomicheskie indicatory i polozhenie pensionerov, Russian Economic Development, 25(9): 57-74.

Clapham, D. 2019. Remaking Housing Policy, London: Routledge 
Gel'man V. and Starodubtsev, A. 2016. Opportunities and constraints of authoritarian modernisation: Policy reforms in Russia in the 2000s, Europe-Asia Studies, 68(1): 97-117.

Gosudarstvennaya programma Rossiyskoy Federatsii 'Obespechenie dostupnym i komfortnym zhil'yem i kommunal 'nymi uslugami grazhdan Rossiyskoy Federatsii', adopted 15 April 2014, available at http://www.minstroyrf.ru/trades/realizaciya-gosudarstvennyh-programm/29/, accessed December 2019.

Grishina, E. and Tsatsura, E. 2018. Material'noe polozhenie semei ispol'zovavshikh federal'nyi materinskiy capital, Upravlenije Ekonomicheskimi Sistemami, 9(115): 39-53.

Gunko, M., Bogacheva, P. Medvedev, A., and Kashnitsky, I., 2018. Path-dependent development of mass housing in Moscow, Russia, in Hess, D.B. et al. (eds.), Housing Estates in Europe, Berlin: Springer, 289-311.

Kivinen, M. 2020. Specificities of middle-class structuration in Russia, Social Distinctions in Contemporary Russia: Waiting for the Middle Class Society, London: Routledge: PP-PP.

Khmelnitskaya, M. 2014. Russian housing finance policy: state-led institutional evolution, Post-Communist Economies, 26(2): 149-175.

Khmelnitskaya, M. 2015. The Policy-Making Process and Social Learning in Russia: The Case of Housing Policy, Basingstoke: Palgrave Macmillan.

Khmelnitskaya, M. 2017a. Tools of government for Russian development: The case of housing policy, Russian Politics, 2(3): 307-333.

Khmelnitskaya, M. 2017b. The social budget policy process in Russia at a time of crisis, PostCommunist Economies, 29(4): 457-475.

Khmelnitskaya, M. 2017c. The role of policy experts in social policy-making in Russia: The case of housing, Russian Analytical Digest, 199(27 February): 2-5.

Kulmala, M., Kainu, M., Nikula, J., and Kivinen, M. 2014. Paradoxes of agency: democracy and welfare in Russia, Demokratizatsiya, 22(4): 523-552.

Li, P., Gorshkov, M.K., Scalon, C., and Sharma, K.L. (eds.) 2013. Handbook on Social Stratification in the BRIC Countries: Change and Perspective, Singapore: World Scientific Publishing.

Maleva, T. (ed.) 2017. Monthly Monitoring of the Socio-economic Situation and Perceptions of the Population: 2015 - November 2017, available at https://www.ranepa.ru/social/informatsionno-analiticheskij-byulleten, accessed January 2019.

Maleva, T. (ed.) 2018. Monthly Monitoring of the Socio-economic Situation and Perceptions of the Population: 2015 - November 2018, available at https://www.ranepa.ru/images/News/2018-12/19-12-2018-monitoring.pdf, accessed January 2019.

PFRF 2018a. V 2017 godu PFR vydal 725 tys. sertifikatov na materinskiy kapital, 22 January, available at http://www.pfrf.ru/press_center/ 2018/01/22/151428, accessed 13 December 2018 .

[Type here] 
PFRF 2018b. V Mosckve proshlo rasshirennoe zasedanie pravleniya PFR, 11 December, available at http://www.pfrf.ru/press_center/ 2018/12/11/172366, accessed 13 December 2018.

Putin, V. 2005. Poslanie Federal'nomu Sobraniyu, 25 April, http://www.kremlin.ru/events/president/transcripts/22931, accessed December 2018.

Rosstat (Federal State Statistics Service) 2019. Housing: Housing stock, Provision of Dwellings to Population, http://www.gks.ru/wps/wcm/connect/rosstat_main/rosstat/ru/statistics/population/housing/\#, accessed February 2019.

Sinel'nikov-Murylev, S.G. and Radygin, A.D. (eds.) 2018. Russian Economy in 2017: Trends and Outlooks, Moscow: Gaidar Institute.

Zavisca, J. 2012. Housing the New Russia, Ithaca \& London: Cornell University Press.

Zubarevich, N., Khasanova, R., and Mkrtchyan, N. 2017. Rossiyskie regiony v 2017 g.: sotsial'nie i demographicheskie protsessy, Ekonomicheskoe Razvitiye Rossii, 12: 85-98.

\footnotetext{
${ }^{i}$ See the chapter by Mikhail Chernysh (in this volume) for an analysis of the intergenerational mobility that includes the consideration of housing mobility.

ii Rosstat, http://www.gks.ru/wps/wcm/connect/rosstat_main/rosstat/ru/statistics/population/poverty/\# accessed December 2018.

iii See for instance: https://www.mos.ru/otvet-socialnaya-podderjka/kak-vstat-na-zhilischnyy-uchet/. A socially guaranteed norm in the regions is determined by local governments, taking into account the socio-demographic characteristics, the waiting times for social housing and other characteristics. Yet, it cannot be less than 6 sq. metres, which is a national minimum norm.

iv Including $88.6 \%$ owned by individuals and $2.5 \%$ by legal entities. See: Obshchaya ploshchad' zhilikh pomeshcheniy na konets goda, EMISS, available at https://fedstat.ru/indicator/40454, accessed January 2019.

${ }^{v}$ Housing: Provision of dwellings to population / Rosstat (Federal State Statistics Service), 2019,

http://www.gks.ru/wps/wcm/connect/rosstat_main/rosstat/ru/statistics/population/housing/\#, accessed February 2019

vi GKS-KOUZH-2016 Comprehensive monitoring of living conditions 2016, available at: http://www.gks.ru/free doc/new_site/KOUZ16/index.html accessed December 2018

vii An alternative classification would be based on the individual characteristics of the breadwinner. Such classification would produce the following three groups of households: $20 \%$ middle, $49 \%$ working and $32 \%$ nonworking families. Therefore, if only the breadwinner's status is taken into account, the group of the mixed type of households from Figure 1 would be split evenly between the middle- and working-class categories. Yet, to follow the logic of the SDMR survey, in which not only breadwinners but other members of their households were surveyed, in our analysis we choose to follow the first definition of the household class belonging.

viii Truncation procedure of values less than 6 and greater than 300 was applied to the SDMR-2015 data on the aggregate space of a house or apartment.

ix See Rosstat data at http://www.gks.ru/wps/wcm/connect/rosstat_main/rosstat/ru/statistics/population/level/\#, accessed December 2018.

${ }^{\mathrm{x}}$ Here the data do not allow us to separate mortgage payment arrears from missed rent payments. This is because the survey recorded the type of housing at the time of the survey was conducted, instead of, for instance, recording the household tenure over the year's period. Such an alternative recording of data would have allowed an analyst to detect changes in such cases as when a hypothetical individual had been renting for six months, and then bought a flat or moved in with their parents or friends for the second half of the year.

xi See for instance: https://www.novayagazeta.ru/articles/2018/12/10/78862-bunt-v-dolgovoy-yame,

http://www.poluostrov-kamchatka.ru/pknews/detail.php?ID=218290 and
} 
https://arigus.tv/news/item/122330/?r1=ya\&utm_source=yxnews\&utm_medium=desktop accessed December 2018.

xii https://www.levada.ru/indikatory/odobrenie-organov-vlasti/ accessed March 2019. Yet, it can be noted that the opinion polls show that trust in the president has been decreasing since mid-2018. Thus, in 2018 for the first time institutional trust in the president was overtaken by trust in another institution, the army. See https://www.levada.ru/2018/10/04/institutsionalnoe-doverie-4/ accessed March 2019.

xiii RBC, Novosibirskij gubernator povysil tarify ZHKKH na 15\% [Novosibirsk Governor raised tariffs for housing and communal services by 15\%], 20 December 2016, available at https://www.rbc.ru/nsk/freenews/5858a6599a7947039847, accessed January 2019.

xiv The median Russian adult has lived in the same dwelling for 20 years, according to the 2011 wave of Russia's Generations and Gender Panel Survey (GGS). GGS-2011 is an all-Russia representative survey of 11,184 people aged 17-87. Available at http://sophist.hse.ru/db/oprosy.shtml?ts=204\&en=0, see, variable 1.234, accessed February 2019. 